\title{
Contributions
}

Juan Du* and Takeshi Yagihashi

\section{Health Care Use, Out-of-Pocket Expenditure, and Macroeconomic Conditions during the Great Recession}

\begin{abstract}
We study how macroeconomic conditions during the Great Recession affected health care utilization and out-of-pocket expenditures of American households. We use two data sources: the Consumer Expenditure (CE) Survey and the Survey of Income and Program Participation (SIPP); each has its own advantages. The CE contains quarterly frequency variables, and the SIPP provides panel data at the individual level. Consistent evidence across the two datasets shows that utilization of routine medical care was counter-cyclical, whereas hospital care was pro-cyclical during the Great Recession. When we examine the pre-recession period, the relationship between macroeconomic conditions and health care use was either non-existent or in opposite directions, suggesting that this relationship may have been unique to the Great Recession.
\end{abstract}

Keywords: health care utilization, health insurance, unemployment

\section{Introduction}

In this paper, we study the relationship between economic crisis and medical care use. Literature on the relationship between the business cycle, health, and health insurance find that insurance coverage is typically pro-cyclical (Gruber and Levitt 2002; Holahan and Garrett 2009; Gilmer and Kronick 2009; Cawley and Simon 2005, Cawley, Moriya, and Simon, 2011), whereas some measures of individuals'

*Corresponding author: Juan Du, Department of Economics, Old Dominion University, Constant Hall 2021, Norfolk, VA 23529, USA, E-mail: jdu@odu.edu

Takeshi Yagihashi, Department of Economics, Old Dominion University, Constant Hall 2021, Norfolk, VA 23529, USA, E-mail: tyagihas@odu.edu 
health are counter-cyclical (e.g. Ruhm 2000, 2003, 2005). Because medical care use is driven by both health and household financial resources, the relationship between business cycles and health care utilization is difficult to predict.

Several papers in the literature find that routine medical exams and medical care are negatively affected by unemployment (Ruhm 2000; Lusardi, Schneider, and Tufano, 2014), ${ }^{1}$ while others find the opposite or inconclusive evidence. For example, Dehejia and Lleras-Muney (2004) show that unemployment is associated with more doctor visits for pregnant women. McInerney and Mellor (2012) find that inpatient care for seniors increases as the unemployment rate rises. Ruhm (2003) finds a positive but statistically insignificant relationship between unemployment and medical care utilization for primary-age workers.

One limitation of these studies is that all of them use annual-frequency data, but macroeconomic conditions are fast-moving and fluctuate much within a year, particularly during economic expansions and contractions. For example, in January 2009 the national unemployment rate was $7.8 \%$ and by December of the same year it was $9.9 \%$. If the unemployment rate tracks labor market conditions closely, then households may adjust their health care decisions accordingly. Thus, using annual-frequency data to study the effect of macroeconomic conditions on medical care may potentially obscure the contemporaneous relationship existing in quarterly-frequency data.

Finding high-frequency microeconomic data is a challenge because most publicly available data on health care are either low frequency or lack detailed information on health care expenditures. In this paper, we use two data sources to study the impact of macroeconomic conditions. Our main data source is the Consumer Expenditure (CE) Survey. The CE interviews are conducted quarterly and contain detailed information on disaggregated health care expenditures at the household level, which allows us to match expenditures with macroeconomic conditions every 3 months. Our second data source is the Survey of Income and Program Participation (SIPP) that contains utilization and expenditure information at the individual level. The core interviews of the SIPP are conducted every 4 months apart, but variables for health care utilization and expenditures are only available in its topical module. The topical module interviews are conducted annually, at which time health care utilization is recorded for the period of the past 12 months. Both datasets cover the Great Recession period and contain state identifiers that permit macroeconomic

1 Ruhm (2000) finds that preventive medical care (such as, routine medical checkup and pap smears) is negatively correlated with unemployment using annual-frequency data from 1972 to 1991. Lusardi, Schneider, and Tufano (2014) show that routine health care utilization has decreased during June and July of 2009 in a cross-national survey. 
variables to be linked to household or individual-level variables. The advantage of the CE is its higher interview frequency and detailed expenditure data, whereas the SIPP is panel data, which allows us to track the same individuals for several years.

This study provides several contributions to the literature: First, we examine the impact of the macroeconomy on health care utilization and out-of-pocket expenditure using two different datasets, with one of them collecting information at a higher frequency than is the convention in the literature; second, we explore the relationship between macroeconomic conditions and use of medical care by detailed categories; third, we study whether the relationship was the same before and during the Great Recession; fourth, we examine the effect of macroeconomic conditions by gender and household insurance status, while controlling for endogeneity of health insurance.

Our findings suggest that health care utilization does vary with the business cycle. In particular, the probability of using any care increased, whereas out-ofpocket expenditure conditional on use decreased during the Great Recession. We show that the effects of macroeconomic conditions differed by type of health care services, gender, and household insurance status. When we examine the pre-recession period (4 years before the Great Recession) using the same regressions, we find macroeconomic conditions had either no effect or the opposite effect on health care utilization. This suggests that the relationship may have been unique to the Great Recession.

Given that the nationwide unemployment rate increased from $5 \%$ in December 2007 to $9.5 \%$ in June 2009, our model (based on the SIPP estimates) predicts that the percentage of individuals using any medical care would increase by $4.1 \%$ points. The percentage of individuals visiting a physician would increase from $68.5 \%$ to $74.6 \%$ (i.e. a $6.1 \%$ point increase), and the percentage of individuals having a hospital inpatient stay would decrease from $10.2 \%$ to $6.6 \%$ (i.e. a $3.6 \%$ point decrease). In addition, annual out-of-pocket expenditures would decrease by about $\$ 35$ on average.

Our results indicate the responses to macroeconomic conditions were heterogeneous and were particularly large and perhaps unique during the Great Recession. If macroeconomic shocks in the labor market affect health care utilization and out-of-pocket expenditures, they may in turn affect the subsequent health of and economic outcomes in American households.

This paper is organized as follows. In Section 2, we provide a conceptual framework for discussion. In Section 3, we explain the details of the estimation method. In Section 4, we introduce the two datasets, discuss their differences, and provide summary statistics. The main results are summarized in Section 5. Comparison of the Great Recession vs the pre-recession period and the high- vs 
the low-frequency data are shown in Sections 6 and 7. Sensitivity analysis is conducted in Section 8. The last section concludes.

\section{Background and conceptual framework}

The Great Recession was an 18-month-long economic contraction that generated a large reduction in employment and income (Elsby, Hobijn, and Sahin 2010; Farber 2011). The unemployment rate increased from 5\% in December 2007 to 9.9\% at the beginning of 2010. The Great Recession was different from previous recessions because recovery in employment has been relatively slow. In the 3 years after the recession officially ended in June 2009, the unemployment rate had just fallen by $1.3 \%$ points (from $9.5 \%$ in June 2009 to $8.2 \%$ in June 2012). Meanwhile from 2007 to 2010, the number of uninsured individuals rose from 44.1 million to 50 million (the Census Bureau), whereas real personal consumption expenditure on health care services increased by an average of $1.8 \%$ annually during the same period. ${ }^{2}$ The increase in real health care expenditure was in contrast to the shrinkage of the other service sectors (for example, food, transportation, and recreational services all incurred a decline) during the same period.

As the unemployment rate rises during recessions, health care utilization may increase or decrease because of several factors that work in opposite directions. On the one hand, facing declining wages (and a lower opportunity cost of time), households may substitute regular consumption for health-related consumption because health-related activities are more time intensive. Vistnes and Hamilton (1995) show that parents' longer work hours and higher opportunity costs of time are associated with fewer doctor visits for children. Xu (2013) finds that people are less likely to engage in time-intensive activities during economic expansions. On the other hand, the income effect associated with lower wages decreases both regular consumption and health-related consumption. The income effect may be particularly large for low-income households and for households that have to pay the full cost of health care services (such as the uninsured).

Several other factors may complicate the relationship. First, insurance status may vary during recessions. During the Great Recession, many people lost or forewent employer-provided insurance, while others gained public insurance.

2 Source: Bureau of Economic Analysis, table 2.3.3 Real Personal Consumption Expenditure by Major Product. 
According to the U.S. Census Bureau, Medicaid enrollment increased from 44.4 million in 2007 to 47.5 million in $2010 .^{3}$ Second, health may improve or deteriorate during recessions. Literature on the relationship between business cycles and health has provided mixed results. Several studies suggest that health deteriorates due to the psychological stress and/or the unhealthy behaviors associated with stress during recessions (e.g. Brenner and Mooney 1983; Charles and DeCicca 2008; Davalos, Fang, and French 2012; Latif 2014). Others find that health may improve because of reduced numbers of motor vehicle accidents, changes of lifestyles, and a decrease of risky behaviors (e.g. Freeman 1999; Ruhm 2000, 2005; Ruhm and Black 2002; Miller et al. 2009; Colman and Dave 2013). Due to these several factors working in opposite directions, the relationship between medical care use and economic crisis is ambiguous.

How macroeconomic conditions affect out-of-pocket health care expenditures is even harder to predict because it depends on the type and price of health care services used as well as the level of insurance benefits, if any. Facing financial distress and loss of insurance coverage, households may forego expensive services (such as surgery) if they can be replaced by cheaper alternatives (such as physician visits and drugs).

In addition to total expenditure, we examine three subcategories of services. They are physician visits, prescription drug use, and hospital utilization. Physician visits and prescription drug use are more routine in nature; they may increase during recessions if time cost is an important factor in deterring care and the associated income effect is relatively small. Hospital care is often the result of an urgent health condition (such as heart attack, stroke) and accidents, which may also fluctuate with the business cycle.

\section{Estimation method}

One challenge of modeling health care expenditure/utilization data is that the distribution is usually non-normal with a positive skewness and a significant portion of zeros. For example, 95\% of our sample (CE) had not used hospital care and 43\% had not incurred any health care expenses in the previous 3 months. No standard distribution would provide a good fit to such data. Following the health economics literature (Duan et al. 1983; Mullahy 1998; Manning and Mullahy 2001) and the RAND Health Insurance Experiment,

3 Data source: http://www.census.gov/compendia/statab/2012/tables/12s0146.pdf, table 146. 
we use a mixture type of model, the two-part model, to estimate health care utilization. The two-part model (hereafter, TPM) has the flexibility of treating the zeros and non-zeros as generated by two separate and uncorrelated processes. $^{4}$

The first part of the TPM estimates the probability of using any medical care (utilization equation), and the second part estimates expenditure conditional on use (expenditure equation). Specifically, the TPM can be written as

$$
\begin{gathered}
\operatorname{Pr}\left(H_{\text {ist }}>0\right)=\alpha_{1} x_{\text {ist }}+\alpha_{2} z_{\text {st }}+\omega_{s}+\theta_{t}+\epsilon_{1, i s t} \\
\ln \left(H_{\text {ist }}\right) \mid\left(H_{\text {ist }}>0\right)=\alpha_{3} x_{\text {ist }}+\alpha_{4} z_{s t}+\omega_{s}+\theta_{t}+\epsilon_{2, \text { ist }} \\
i=1 \ldots, N(\text { households }), s=1, \ldots, S(\text { state }), t=1, \ldots, T(\text { time })
\end{gathered}
$$

where eq. [1] is the utilization equation and eq. [2] is the expenditure equation. $\ln \left(H_{\text {ist }}\right)$ is the log-transformed real out-of-pocket health care expenditure for the individual/household $i$ in state $s$ at time $t$, and $\ln (H) \mid(H>0)$ is expenditure conditional on use. $x$ is a set of individual/household demographic and socioeconomic variables, and $z$ is a set of state-level variables that represent macroeconomic conditions in the state that the person is living in. Time fixed effects $\theta_{t}$ are included to control for the common shocks that occur in a particular period. State fixed effects $\omega_{s}$ are used to control for time-invariant factors unique to each state, such as industrial composition and cost of living.

For the CE, the utilization equation is estimated using the probit model, and the expenditure equation is estimated using the least squares method on logtransformed variables. We also include year dummies, month dummies, and state dummies in each regression. For the SIPP, we use the fixed effects linear model to estimate both utilization and out-of-pocket expenditures. ${ }^{5}$ We additionally include year and state dummies in the individual fixed effects models.

Following the literature, we use state unemployment rates as the key indicator for the macroeconomy. While state macroeconomic variables co-move with their national counterparts, unemployment rates vary greatly by state. For example, in 2010, the unemployment rates in North Dakota, South Dakota, and Nebraska were below 6\% while they were above 11\% for South Carolina, Rhode Island, Nevada, Michigan, Florida, and California. The effect of macroeconomic

\footnotetext{
4 The alternative is a sample-selection model that treats the non-zeros as a selected sample, allowing the errors of the two parts to be correlated.

5 We do not use the fixed effects logit model because a significant number of observations would be dropped due to lack of change in utilization status during the sample period. We additionally include year and state dummies in the individual fixed effects models.
} 
variables is identified by the severity and timing of the business cycle across states. In the CE, we use 3-month averages of the unemployment rate preceding the interview month to construct quarterly time series that match the timing of health care expenditures. In the SIPP, we construct 12-month averages of the unemployment rate.

We include additional state-level variables that vary with the business cycle and may affect utilization. These variables are state tax revenue per capita, wages per health care worker, and state housing prices. Tax revenue represents general state economic activities. Wages per health care worker is an important component of overall health care cost. A higher housing price is typically associated with a higher rent or mortgage payment, which may limit households' resources for medical care. ${ }^{6}$ We deflate tax revenue, wages, and housing prices by the corresponding regional price index obtained from the Bureau of Labor Statistics (BLS). ${ }^{7}$ All variables are measured at the quarterly frequency. They are lagged one quarter to match the timing in the CE and four quarters to match the timing in the SIPP.

\section{Data}

We use two datasets in this paper, the CE Survey and Survey of Income and Program Participation (SIPP). We first provide background information for each survey, highlighting the differences between them, and then report descriptive statistics.

\subsection{Data description}

The CE is a quarterly frequency survey conducted by the BLS. It asks each household about their health care expenditures in detailed categories of health

6 State tax revenue is obtained from the U.S. Census quarterly summary of state and local taxes. Wages per health care workers are constructed using total wages for health care workers divided by the number of health care workers employed in each state. Wages and employment for health care and social assistance workers are obtained from the Bureau of Economic Analysis website. State-level housing price index is obtained from the Federal Housing Finance Agency website $(1980=100$, NSA $)$.

7 The BLS collects comparable regional-level price data for four regions (Northeast, Midwest, South, and West) and three metropolitan areas (NY-NJ-CT-PA, Los Angeles-Riverside-Orange County, Chicago-Gary-Kenosha) at the monthly frequency. There are no comparable state-level price data available. 
care services in the previous 3 months. ${ }^{8}$ The CE is a rotating panel that interviews the same household for a maximum of five continuous quarters. Data from the first interview are not available for public use; hence only four waves are available. Due to the short rotating nature of the data, we are unable to track individual households throughout the Great Recession, thus we use the CE as a pooled cross-section. The number of households interviewed in each quarter is spread evenly across the 3 months, and approximately 1,500-2,000 households are interviewed per month, ${ }^{9}$ thus our sample contains observations for every month during 2007-2010. To avoid the complicated error structure caused by individual households appearing multiple times, we include households from the second wave only. ${ }^{10}$ We do include information from all waves in additional analysis. One limitation of the CE is that we are unable to obtain individual-level health care expenditures because it is a household-level survey.

To overcome the drawbacks of the CE, we use a second dataset in our analysis. The SIPP is a survey conducted by the US Census Bureau. It is a panel dataset that follows the same individuals over a maximum duration of 4 years, with an interview conducted every 4 months. For example, the 2008 panel starts from August 2008 and lasts until August 2012, providing a maximum of 12 interview waves that are available for each individual. The SIPP consists of two categories of questions: core and topical. The core interview covers fundamentals such as an individual's demographic and socio-economic characteristics, employment, and income, etc. The topical modules cover special topics such as health, childcare, and retirement. Since the topical module on health is only available in waves 4, 7, and 10 of the 2008 panel, we could only track health care utilization and expenditure at the annual frequency. ${ }^{11}$

The key differences between the CE and SIPP are summarized as follows. First, the frequency of observation is different. Health care utilization in the $\mathrm{CE}$ is for the 3 months before the interview month, whereas utilization in the

8 The CE defines a household as a consumer unit, which consists of two cases: (1) two or more people related by marriage, blood, adoption, or other legal arrangement and who make joint financial decisions; (2) a person living alone, or sharing a house or lodging home with others, and this person must be financially independent.

9 The households interviewed in the same month can be from any of the five waves.

10 We conducted robust analysis with households in the third wave and find very similar results.

11 Wave 4 interview was conducted in August 2009. In this interview, respondents were asked about their health care utilization in the previous 12 months, that is, from August 2008 to July 2009. Wave 7 and wave 10 interviews were conducted in August 2010 and August 2011, respectively. 
SIPP is for the 12-month period before the interview. As a result, macroeconomic variables are constructed at the quarterly frequency in the $\mathrm{CE}$ and the annual frequency in the SIPP. Second, health care utilization and expenditure variables are collected at the household level in the $\mathrm{CE}$, whereas individual-level information is available in the SIPP. Third, we use the CE as a pooled cross-section and the SIPP as a panel. Fourth, the sample period in the CE is January 2007-December 2010, and the sample period in the SIPP is August 2008-2011. Lastly, the SIPP has a larger sample size than the CE.

We focus on the working-age population (16-64 years old) and exclude individuals over 64 years old (SIPP) or households that have members over 64 years old (CE) because most elderly (65 and older) in the United States are enrolled in Medicare (thus having little fluctuation in insurance status) and many of them do not work full-time (thus less likely to be affected by business cycles). In the CE, we additionally restrict the sample to singles and households that consist of spouse and/or children and exclude households with other persons present (such as siblings, relatives, friends, and domestic partners). This is because insurance and medical care decisions for the latter are more complicated.

The CE survey suppresses or recodes state information for some observations to meet the criterion of the Census Disclosure Review Board. In the baseline analysis, we drop the observations with either state missing (15\% of the sample) or recoding (4\%). This should not be a concern for selection bias because the missing observations are not based on health care utilization or any of the independent variables. We nevertheless perform additional analysis to include this subsample (see Section 8). Our final sample in the CE consists of 12,695 observations in 33 states (including Washington, DC).

The SIPP does not suppress or recode state information. The final sample consists of individuals from all 50 states plus Washington, DC. The final sample size is 93,004 (or 32,643 individuals) after adjusting for missing values and dropping observations that do not have a sample weight.

\subsection{Outcome variables}

To keep consistency across the two datasets, we use the same variable definitions whenever possible. Detailed definitions of all variables are shown in Table 1 for the CE and Table 2 for the SIPP. Our outcome variables are overall health care utilization, physician visits, hospital care, prescription drug use, and total out-of-pocket expenditures. In estimation, we convert nominal 
Table 1: Summary statistics for the CE (2007-2010)

\begin{tabular}{|c|c|c|}
\hline & Variable definition & $\begin{array}{r}\text { Sample mean } \\
\text { (st. dev) }\end{array}$ \\
\hline Sample size & & 12,965 \\
\hline $\begin{array}{l}\text { Health care utilization } \\
\text { and expenditure }\end{array}$ & Frequency: previous 3 months & \\
\hline Any medical care & $=1$ if incurred positive medical expense & 0.57 \\
\hline Any physician visit & $\begin{array}{l}=1 \text { if incurred expense on visit to physician or medical } \\
\text { professionals }\end{array}$ & 0.31 \\
\hline Any prescription drug & $=1$ if incurred expense on prescription drugs & 0.37 \\
\hline Any hospital care & $=1$ if incurred expense on hospital room or services & 0.05 \\
\hline Out-of-pocket expense & $\begin{array}{l}\text { Total household out-of-pocket expenditure less of } \\
\text { reimbursement, conditional on use }\end{array}$ & $\begin{array}{r}516.29 \\
(905.60)\end{array}$ \\
\hline \multicolumn{3}{|l|}{ Macroeconomic variables } \\
\hline State unemployment rate & $\begin{array}{l}\text { State unemployment rate averaged for the } \\
\text { past } 3 \text { months }\end{array}$ & $\begin{array}{r}7.09 \\
(2.74)\end{array}$ \\
\hline $\begin{array}{l}\text { State tax revenue per } \\
\text { person }\end{array}$ & $\begin{array}{l}\text { State tax revenue divided by state population, deflated } \\
\text { with regional price index }\end{array}$ & $\begin{array}{r}2.76 \\
(0.88)\end{array}$ \\
\hline $\begin{array}{l}\text { Wage per health care } \\
\text { worker }\end{array}$ & $\begin{array}{l}\text { Total real wages in a state divided by number of } \\
\text { employees for health care and social assistance } \\
\text { workers }\end{array}$ & $\begin{array}{l}198.62 \\
(25.92)\end{array}$ \\
\hline State housing price index & $\begin{array}{l}\text { State-level housing prices deflated by regional } \\
\text { price index }\end{array}$ & $\begin{array}{r}1.78 \\
(0.52)\end{array}$ \\
\hline $\begin{array}{l}\text { Simulated Medicaid } \\
\quad \text { eligibility }\end{array}$ & Medicaid eligibility for adults & $\begin{array}{r}0.12 \\
(0.09)\end{array}$ \\
\hline \multicolumn{3}{|l|}{ Household-level variables } \\
\hline Age & Age of the reference person (ref. person) & $42.91(11.80)$ \\
\hline Male (binary) & $=1$ if the ref. person is a male & 0.50 \\
\hline $\begin{array}{l}\text { White non-Hispanic } \\
\text { (binary) }\end{array}$ & $=1$ if the ref. person is White excl. Hispanic & 0.69 \\
\hline $\begin{array}{l}\text { Black non-Hispanic } \\
\text { (binary) }\end{array}$ & $=1$ if the ref. person is Black excl. Hispanic & 0.11 \\
\hline Hispanic (binary) & $=1$ if the ref. person is Hispanic & 0.14 \\
\hline Other race (binary) & $=1$ if the ref. person belongs to other races & 0.06 \\
\hline Married (binary) & $\begin{array}{l}=1 \text { if the ref. person is married with spouse } \\
\text { present }\end{array}$ & 0.61 \\
\hline No. children less than 2 & Number of children less than 2 years old & $\begin{array}{r}0.07 \\
(0.27)\end{array}$ \\
\hline No. children 2 to 15 & Number of children between 2 and 15 years old & $\begin{array}{r}0.61 \\
(0.98)\end{array}$ \\
\hline Some college (binary) & $\begin{array}{l}=1 \text { if the ref. person attended some college (greater than } \\
12 \text { years and less than } 16 \text { years of schooling) }\end{array}$ & 0.55 \\
\hline $\begin{array}{l}\text { High school graduates } \\
\text { (binary) }\end{array}$ & $=1$ if graduated high school ( $=12$ years of schooling) & 0.22 \\
\hline
\end{tabular}


Table 1: (Continued)

\begin{tabular}{llr}
\hline & Variable definition & $\begin{array}{r}\text { Sample mean } \\
\text { (st. dev) }\end{array}$ \\
\hline $\begin{array}{llr}\text { Less than high school } \\
\text { (binary) }\end{array}$ & $=1$ if did not finish high school (<12 years of schooling) & 0.10 \\
Healthbad (binary) & $=1$ if any household member has an illness or disability & 0.06 \\
& that prevents them from working & $1,607.85$ \\
Annual hours worked & Total annual hours worked of the ref. person (divided by & $(1,026.09)$ \\
Self-employed (binary) & 1,000 in estimation) & 0.08 \\
Unemployment income & $=1$ if the ref. person is self-employed & 0.05 \\
(binary) & $=1$ if the household has unemployment income & $65,223.23$ \\
Household salary income & Total household salary income (logged form is used in & $(64,027.84)$ \\
Full insurance & estimation) & 0.74 \\
Uninsured (binary) & $=1$ if all family members have insurance & 0.18 \\
Partial insured (binary) & $=1$ if no insurance policy is reported & $=1$ if some but not all household members are uninsured \\
\hline
\end{tabular}

Notes: Sample means are adjusted using the sample weight provided by the CE. Standard deviations for continuous variables are shown in parentheses. Sample period is from January 2007 to December 2010. For households with more than one member, information of the reference person is used to construct demographic and socio-economic variables. State tax revenue, wage per health care worker, and state housing price index are adjusted using regional CPI.

Table 2: Summary statistics for the SIPP (2008-2011)

Sample mean

Variable definition

(st. dev)

Sample size

93,004

Health care utilization and expenditure

Any medical care

Any physician visit

Any prescription drug

Any hospital care

Out-of-pocket expense

\section{Frequency: previous 12 months}

$=1$ if incurred positive out-of-pocket expenditure

$=1$ if had a visit or contact with a medical provider

0.74

$=1$ if took prescription medication

$=1$ if stayed in a hospital overnight or longer

Total individual out-of-pocket expenditure less of

reimbursement, conditional on use

$(1,182.34)$

\section{Macroeconomic variables}

State unemployment rate Same definition as in Table 1

$8.71(1.98)$

State tax revenue per

person

Wage per health care

$203.17(54.19)$ 
Table 2: (Continued)

\begin{tabular}{|c|c|c|}
\hline & Variable definition & $\begin{array}{r}\text { Sample mean } \\
\text { (st. dev) }\end{array}$ \\
\hline State housing price index & & $\begin{array}{r}1.55 \\
(0.49)\end{array}$ \\
\hline \multicolumn{3}{|l|}{ Individual-level variables } \\
\hline Age & Age of the individual & $39.61(13.83)$ \\
\hline Male (binary) & $=1$ if the person is a male & 0.49 \\
\hline $\begin{array}{l}\text { White non-Hispanic } \\
\text { (binary) }\end{array}$ & $=1$ if the person is White excl. Hispanic & 0.66 \\
\hline $\begin{array}{l}\text { Black non-Hispanic } \\
\text { (binary) }\end{array}$ & $=1$ if the person is Black excl. Hispanic & 0.12 \\
\hline Hispanic (binary) & $=1$ if the person is Hispanic & 0.15 \\
\hline Other race (binary) & $=1$ if the person belongs to other races & 0.07 \\
\hline Married (binary) & $=1$ if the person is married & 0.54 \\
\hline $\begin{array}{l}\text { Have children less than } 2 \\
\text { (binary) }\end{array}$ & $=1$ if has at least one child less than 2 years old & 0.17 \\
\hline $\begin{array}{l}\text { Have children } 2 \text { and } 15 \\
\text { (binary) }\end{array}$ & $=1$ if has at least one child between 2 and 15 years old & 0.46 \\
\hline Some college (binary) & $\begin{array}{l}=1 \text { if attended some college, or has a diploma from a } \\
\text { vocational school, or has an associate degree }\end{array}$ & 0.35 \\
\hline $\begin{array}{l}\text { High school graduates } \\
\text { (binary) }\end{array}$ & $=1$ if has a high school diploma & 0.24 \\
\hline $\begin{array}{l}\text { Less than high school } \\
\text { (binary) }\end{array}$ & $=1$ if has less than high school education & 0.15 \\
\hline Healthbad (binary) & $=1$ if unable to work because of an illness or disability & 0.06 \\
\hline Hours worked & Usual hours worked per week & $28.55(20.39)$ \\
\hline Self-employed (binary) & $=1$ if the person owns or is a partner of a business & 0.05 \\
\hline $\begin{array}{l}\text { Unemployment income } \\
\text { (binary) }\end{array}$ & $=1$ if the family has unemployment income & 0.05 \\
\hline Household salary income & Total family income for the reference month & $\begin{array}{r}5,863.72 \\
(5,635.04)\end{array}$ \\
\hline Always insured (binary) & $=1$ if always insured in the previous 12 months & 0.72 \\
\hline $\begin{array}{l}\text { Always uninsured } \\
\text { (binary) }\end{array}$ & $=1$ if always uninsured in the previous 12 months & 0.13 \\
\hline $\begin{array}{l}\text { Sometimes uninsured } \\
\text { (binary) }\end{array}$ & $\begin{array}{l}=1 \text { if experienced uninsured episode in the previous } 12 \\
\text { months }\end{array}$ & 0.15 \\
\hline
\end{tabular}

Notes: Sample means are adjusted using the sample weight ("Igtpn3wt") provided by the SIPP. Standard deviations for continuous variables are shown in parentheses. Sample period is from August 2008 to 2011. There are three waves of data used (waves 4, 7, and 10). All individual-level variables and macroeconomic variables are constructed using values at the beginning of the utilization period. 
expenditures to 2007 dollars using the consumer price index for medical care services by region and metropolitan areas obtained from the BLS.

In the CE, total health care expenditure includes eye examination, eye care, dental care, hospital rooms and services, services by medical professionals and physicians, lab tests, prescription drugs, adult day care, care in convalescent and nursing homes, medical equipment and supplies, and all combined expenditures. Expenditures for the three subcategories (physician visits, prescription drugs, and hospital care) are constructed by aggregating the relevant items in the detailed expenditures files. ${ }^{12}$ We use positive expenditures to indicate medical care utilization. According to Table 1, 57\% of the households incurred positive medical expenses in a given quarter. Breaking down by type of service, $31 \%$ of the households visited physicians, $5 \%$ had a hospital episode, and 37\% incurred positive expenses on prescription drugs. ${ }^{13}$ For households that incurred positive medical expenses, the average out-ofpocket expense per household is $\$ 516$ per quarter, which is approximately $\$ 588$ per person per year. ${ }^{14}$ This is similar to the $\$ 617$ reported in the Medical Expenditure Panel Survey (MEPS) for medical care users below 65 years old during 2007-2010. ${ }^{15}$

In the SIPP, there are separate questions on utilization and expenditure. The utilization question for physician visit is, "During the past 12 months, that is, since (interview month) 1st of last year, how many times did ... see or talk to a doctor, or nurse, or any other type of medical provider about...'s health?” The respondent was also asked whether he/she used any prescription drugs and whether he/she was a patient in a hospital overnight and the amount of total out-of-pocket expenditure. We use positive expenditures to indicate utilization of any medical care, to be consistent with the CE. The out-of-pocket expense is

12 Physician visits include all physician services (code used in the CE is 420). Hospital care includes both hospital rooms and hospital services $(310,320,330)$. The code for prescription drugs is 620 .

13 We also calculated the annual utilization rate for households that appeared in four consecutive quarters. The overall utilization rate is $82 \%$, which is very similar to the statistics obtained using the SIPP and the MEPS.

14 This is obtained by adding up out-of-pocket expenditures for households that appeared in four consecutive quarters. The average annual expenditure per household is $\$ 1,554$ in the CE. We divide $\$ 1,554$ by the average family size of 2.64 in the sample, which yields $\$ 588$ per person per year.

15 Data Source: MEPS table 1: Total Health Services-Median and Mean Expenses per Person with Expense and Distribution of Expenses by Source of Payment: United States, 2010. 
defined in both datasets as cost adjusted for reimbursement. Summary statistics for the SIPP show that $74 \%$ visited a doctor, $46 \%$ used prescription drugs, and $7 \%$ spent at least one night in a hospital during the preceding 12 months. $^{16}$

\subsection{Covariates}

In the $\mathrm{CE}$, we include demographic and socio-economic variables of the reference person. A reference person is identified as the person who rents or owns the house based on the CE's definition and its requirement of financial independence. If a household's finances depend largely on the person who rents or owns the house, then the characteristics of the reference person may be most relevant to other decisions in the household. ${ }^{17}$ In particular, we include the reference person's age, gender, race, marital status, number and age of children, education, self-employment status, annual hours worked, and the household's salary and unemployment income. We also include a variable that indicates whether the reference person or the spouse is ill or disabled. Our insurance variable is constructed based on whether all household members are covered by insurance. Based on this definition, a household can be either fully insured, uninsured, or partially insured. Partial insurance refers to a situation in which some members in the household are insured while others are not (for example, children are enrolled in Medicaid while parents are not). A household is regarded as uninsured if no insurance policy was reported. ${ }^{18}$

16 According to the MEPS annual estimates from 2007 to 2010, 83\% of individuals under 65 years old had positive medical expenses, 58\% had prescription drug expenses, and $5.5 \%$ had inpatient expenses. MEPS table 1: Total Health Services-Median and Mean Expenses per Person with Expense and Distribution of Expenses by Source of Payment: United States, 2010.

17 In alternative regressions, we used demographic and socio-economic variables of the household earner defined as the one who works and/or provides the primary source of income for the household. We also experimented with including demographic information of the spouse (such as spouse education and employment status) in alternative regressions. These regressions yield similar estimates to our baseline results, thus they are not reported.

18 In the CE, each household is asked the question "Do you or any members in your Consumer Unit have any hospitalization or health insurance plans or belong to a plan that pays all or part of your medical expenses?" If the answer is yes, additional questions on how 
In the SIPP, we include similar demographic and socio-economic variables for the individual. These variables are lagged 1 year so that they reflect the values at the beginning of the utilization period. We categorize insurance status as always insured, always uninsured, and sometimes uninsured during the previous 12 months. Summary statistics for demographic variables adjusted for sample weight are very similar across the two datasets (see Tables 1 and 2).

We note that some of the covariates (such as employment, hours worked, income, and health insurance) may be in the causal pathway from macroeconomic conditions to health care utilization. We conduct several robust analyses later to examine whether the effect of the unemployment rate is affected by the inclusion of these variables.

\subsection{Descriptive statistics and summary figures}

We present time series plots of health care utilization using the CE (Figure 1(A)) and SIPP (Figure 1(B)). The utilization pattern exhibits more fluctuation when we use quarterly data compared with annual data. Overall utilization did not fluctuate much during the Great Recession. Among the subcategories, hospital utilization was relatively stable, whereas physician visits and prescription drug use showed a declining trend from 2007 to 2010, with some fluctuations around the second half of 2008 and beginning of 2009. Based on the summary statistics in the SIPP, hospital utilization continued to decline through 2011 whereas physician visits and prescription drug use recovered somewhat in 2011.

many members are covered under each policy and the type of policy were asked. The same questions were asked for families with Medicaid, as well. For each household, we total the number of persons covered by each policy and divide it by household size. This yields the average number of policies per person. If a household is covered by both private insurance and public insurance, we follow the same procedure. We do not count any special plan, such as eye or dental plans, as separate insurance policies. If the average policy per person is greater than or equal to 1 , we define the household as fully insured. If the average policy is between 0 and 1, we define the household as partially insured. Given the types of families used in our sample, it is rare to have one household member covered by multiple policies while others are uninsured. 

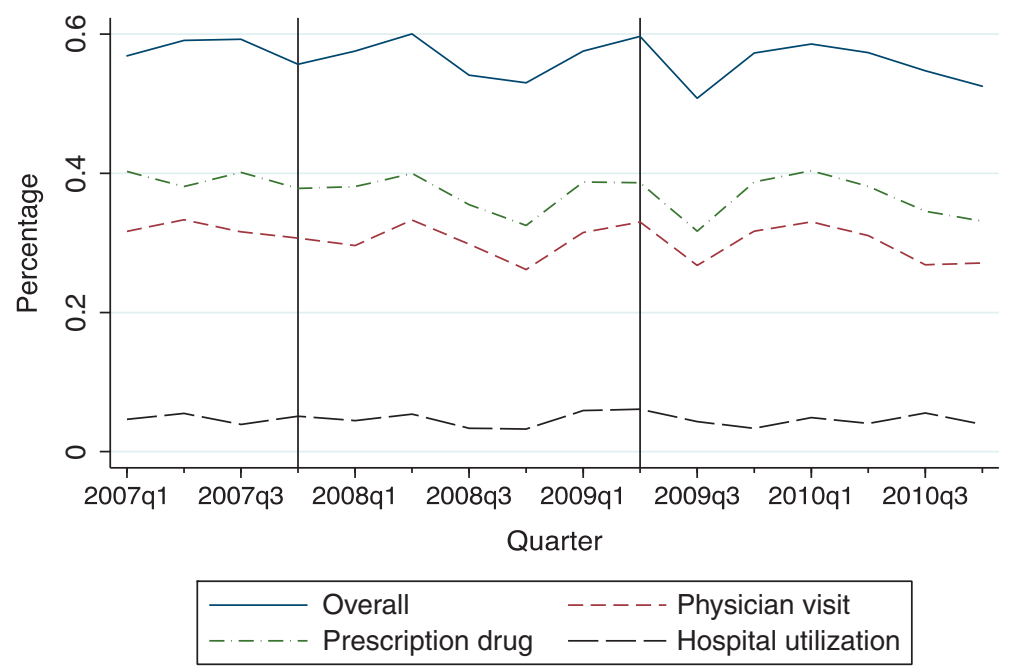

(A)
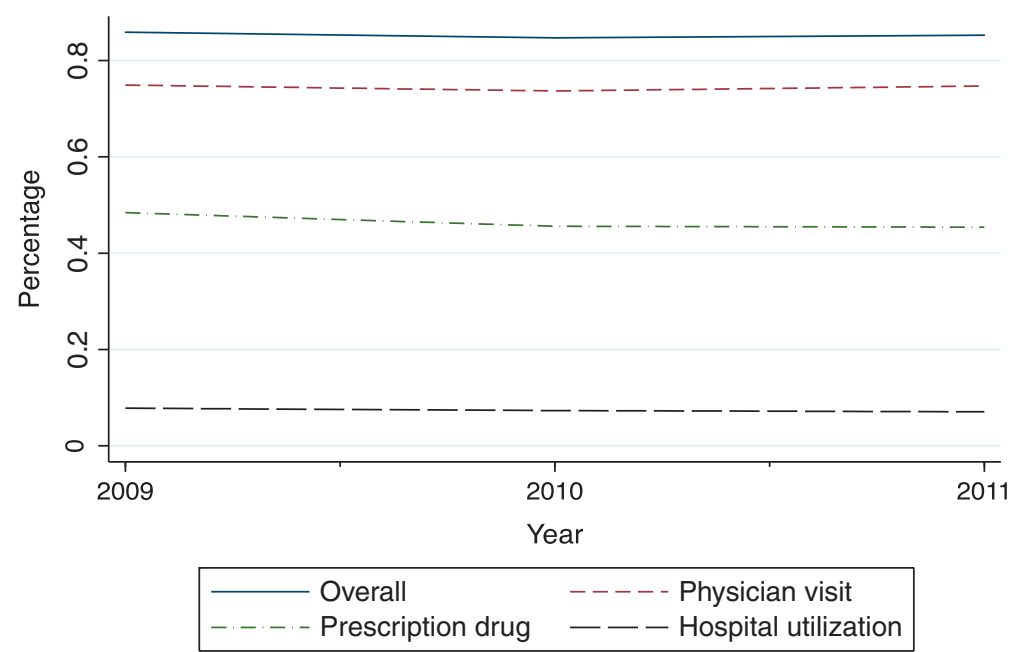

(B)

Figure 1: (A) Medical care utilization in the past 3 months (CE). (B) Medical care utilization in the past 12 months (SIPP)

Note: the two vertical lines in Figure 1(A) represent the start and the end of the Great Recession based on the NBER business cycle dates (http://www.nber.org/cycles.html). 


\section{Results}

\subsection{Effect of macroeconomic conditions on utilization and out-of-pocket expenditures}

Regression results are shown in Tables 3 and 4 for the CE and SIPP, respectively. Average marginal effects are shown for the probit models used in estimating health care utilization.

In the $\mathrm{CE}$, we find that a $1 \%$ point increase in the unemployment rate is associated with a $1.4 \%$ points increase in the probability of overall health care utilization in a given quarter (Table 3). Breaking down by subcategories, the probability of visiting a doctor and using prescription drugs increases by $1.0 \%$ and $1.4 \%$ points, respectively, whereas the probability of hospital care decreases by $0.5 \%$ point. For the SIPP, we find that a $1 \%$ point increase in the unemployment rate is associated with a $1.0 \%$ point increase in overall utilization, a $1.5 \%$ points increase in the probability of a physician visit, a $0.7 \%$ point decrease in hospital inpatient stay, and 3.7\% decrease in out-of-pocket expenditures in a given year. We do not find unemployment to have a statistically significant effect on prescription drug use using the SIPP.

All coefficients in the SIPP (except for prescription drugs) have the same sign as those in the CE. The magnitudes differ somewhat. This could be caused by the difference in interview frequency, unit of observation, and other differences between the two datasets. Since the SIPP measures utilization in the previous 12 months instead of 3 months, we would expect the marginal effects to be larger than those in the CE. This appears to be the case for physician visits and hospital care.

The effects of demographic variables are consistent with expectations. Based on Table 3 (CE results), male, African American, Non-white Hispanic, and households with lower-educated persons are less likely to use medical care than their counterparts. Married couples and households with children are more likely to use health care than singles and households without children. Both datasets provide evidence that being uninsured or becoming uninsured has a negative impact on health care utilization, but has no effect on out-of-pocket expenditures. These results are consistent with the health insurance literature that finds a positive correlation between insurance and health care services (e.g. Currie and Gruber 1996; Cameron et al. 1988; Freeman et al. 2008; Card, Dobkin, and Maestas 2008). 
Table 3: Effect of macroeconomic conditions on health care utilization and out-of-pocket expenditures using the $\mathrm{CE}$

\begin{tabular}{|c|c|c|c|c|c|}
\hline Dependent variable & $\begin{array}{r}\text { Any medical } \\
\text { care }\end{array}$ & $\begin{array}{r}\text { Physician } \\
\text { visit }\end{array}$ & $\begin{array}{r}\text { Hospital } \\
\text { care }\end{array}$ & $\begin{array}{r}\text { Prescription } \\
\text { drug }\end{array}$ & $\begin{array}{r}\text { Out-of-pocket } \\
\text { exp. }\end{array}$ \\
\hline \multicolumn{6}{|l|}{ Macroeconomic conditions } \\
\hline $\begin{array}{l}\text { Unemployment rate (previous } 3 \\
\text { months) }\end{array}$ & $\begin{array}{l}0.014^{\star * *} \\
(0.005)\end{array}$ & $\begin{array}{l}0.010^{\star} \\
(0.005)\end{array}$ & $\begin{array}{l}-0.005^{\star \star} \\
(0.002)\end{array}$ & $\begin{array}{l}0.014^{* *} \\
(0.006)\end{array}$ & $\begin{array}{l}-0.027 \\
(0.022)\end{array}$ \\
\hline State tax revenue per person & $\begin{array}{r}0.004 \\
(0.003)\end{array}$ & $\begin{array}{l}-0.001 \\
(0.003)\end{array}$ & $\begin{array}{l}-0.003 \\
(0.003)\end{array}$ & $\begin{array}{r}0.002 \\
(0.004)\end{array}$ & $\begin{array}{l}-0.019^{\star} \\
(0.011)\end{array}$ \\
\hline Wage per health care worker & $\begin{array}{r}0.000 \\
(0.002)\end{array}$ & $\begin{array}{r}0.001 \\
(0.002)\end{array}$ & $\begin{array}{r}0.000 \\
(0.001)\end{array}$ & $\begin{array}{r}0.000 \\
(0.002)\end{array}$ & $\begin{array}{l}0.020^{\star \star \star *} \\
(0.007)\end{array}$ \\
\hline State housing price index & $\begin{array}{r}0.007 \\
(0.029)\end{array}$ & $\begin{array}{r}0.007 \\
(0.031)\end{array}$ & $\begin{array}{l}-0.011 \\
(0.014)\end{array}$ & $\begin{array}{l}-0.009 \\
(0.038)\end{array}$ & $\begin{array}{r}0.083 \\
(0.122)\end{array}$ \\
\hline \multicolumn{6}{|l|}{ Household-level variables } \\
\hline Uninsured & $\begin{array}{l}-0.184^{\star \star \star} \\
(0.012)\end{array}$ & $\begin{array}{l}-0.136^{\star \star \star} \\
(0.009)\end{array}$ & $\begin{array}{l}-0.012^{\star \star \star} \\
(0.005)\end{array}$ & $\begin{array}{l}-0.152^{\star \star \star} \\
(0.011)\end{array}$ & $\begin{array}{r}0.072 \\
(0.058)\end{array}$ \\
\hline Partial insured & $\begin{array}{l}-0.016 \\
(0.015)\end{array}$ & $\begin{array}{l}-0.016 \\
(0.014)\end{array}$ & $\begin{array}{r}0.005 \\
(0.007)\end{array}$ & $\begin{array}{l}-0.001 \\
(0.016)\end{array}$ & $\begin{array}{l}-0.019 \\
(0.059)\end{array}$ \\
\hline Age & $\begin{array}{l}0.007^{\star \star \star *} \\
(0.000)\end{array}$ & $\begin{array}{l}0.004^{\star \star \star} \\
(0.000)\end{array}$ & $\begin{array}{l}0.001^{\star \star \star} \\
(0.000)\end{array}$ & $\begin{array}{l}0.007^{\star \star \star \star} \\
(0.000)\end{array}$ & $\begin{array}{l}0.025^{\star \star \star *} \\
(0.002)\end{array}$ \\
\hline Male & $\begin{array}{l}-0.075^{\star \star \star} \\
(0.009)\end{array}$ & $\begin{array}{l}-0.048^{\star \star \star} \\
(0.009)\end{array}$ & $\begin{array}{l}-0.012^{\star \star \star} \\
(0.004)\end{array}$ & $\begin{array}{l}-0.074^{\star \star \star} \\
(0.009)\end{array}$ & $\begin{array}{l}-0.058^{\star} \\
(0.030)\end{array}$ \\
\hline African American & $\begin{array}{l}-0.172^{\star \star \star} \\
(0.014)\end{array}$ & $\begin{array}{l}-0.124^{\star \star \star} \\
(0.012)\end{array}$ & $\begin{array}{l}-0.022^{\star \star \star} \\
(0.006)\end{array}$ & $\begin{array}{l}-0.142^{\star \star \star} \\
(0.013)\end{array}$ & $\begin{array}{l}-0.476^{\star \star \star} \\
(0.080)\end{array}$ \\
\hline Non-white Hispanic & $\begin{array}{l}-0.071^{\star \star \star} \\
(0.014)\end{array}$ & $\begin{array}{l}-0.056^{\star \star \star} \\
(0.011)\end{array}$ & $\begin{array}{l}-0.016^{\star \star \star} \\
(0.004)\end{array}$ & $\begin{array}{l}-0.076^{\star \star \star} \\
(0.013)\end{array}$ & $\begin{array}{l}-0.166^{\star \star \star} \\
(0.050)\end{array}$ \\
\hline Other races & $\begin{array}{l}-0.100^{\star \star \star} \\
(0.016)\end{array}$ & $\begin{array}{l}-0.072^{\star \star \star} \\
(0.014)\end{array}$ & $\begin{array}{l}-0.019^{\star \star \star} \\
(0.006)\end{array}$ & $\begin{array}{l}-0.098^{\star \star \star} \\
(0.019)\end{array}$ & $\begin{array}{l}-0.253^{\star \star \star} \\
(0.079)\end{array}$ \\
\hline Married & $\begin{array}{l}0.128^{\star \star \star} \\
(0.011)\end{array}$ & $\begin{array}{l}0.115^{\star \star \star} \\
(0.009)\end{array}$ & $\begin{array}{l}0.019^{* * *} \\
(0.004)\end{array}$ & $\begin{array}{l}0.096^{* * *} \\
(0.010)\end{array}$ & $\begin{array}{l}0.411^{\star * \star} \\
(0.035)\end{array}$ \\
\hline No. of children less than 2 & $\begin{array}{l}0.045^{\star \star \star} \\
(0.015)\end{array}$ & $\begin{array}{l}0.075^{\star \star \star} \\
(0.015)\end{array}$ & $\begin{array}{l}0.037^{\star * \star} \\
(0.005)\end{array}$ & $\begin{array}{r}0.018 \\
(0.017)\end{array}$ & $\begin{array}{l}-0.021 \\
(0.063)\end{array}$ \\
\hline No. of children bet 2 and 15 & $\begin{array}{l}0.020^{* * *} \\
(0.004)\end{array}$ & $\begin{array}{l}0.017^{\star \star *} \\
(0.004)\end{array}$ & $\begin{array}{c}0.003^{\star} \\
(0.002)\end{array}$ & $\begin{array}{l}0.010^{* * *} \\
(0.004)\end{array}$ & $\begin{array}{l}0.055^{\star * \star} \\
(0.019)\end{array}$ \\
\hline Education - some college & $\begin{array}{l}-0.056^{\star * \star} \\
(0.013)\end{array}$ & $\begin{array}{l}-0.016 \\
(0.014)\end{array}$ & $\begin{array}{r}0.001 \\
(0.005)\end{array}$ & $\begin{array}{l}-0.013 \\
(0.012)\end{array}$ & $\begin{array}{l}-0.142^{\star \star \star} \\
(0.044)\end{array}$ \\
\hline Education - high school & $\begin{array}{l}-0.123^{\star \star \star} \\
(0.016)\end{array}$ & $\begin{array}{l}-0.065^{\star \star \star} \\
(0.014)\end{array}$ & $\begin{array}{l}-0.014^{* *} \\
(0.006)\end{array}$ & $\begin{array}{l}-0.060^{* * *} \\
(0.013)\end{array}$ & $\begin{array}{l}-0.340^{\star \star \star} \\
(0.059)\end{array}$ \\
\hline Education $-<$ high school & $\begin{array}{l}-0.206^{\star \star \star} \\
(0.017)\end{array}$ & $\begin{array}{l}-0.117^{\star \star \star} \\
(0.019)\end{array}$ & $\begin{array}{l}-0.017^{\star * \star} \\
(0.006)\end{array}$ & $\begin{array}{l}-0.127^{\star \star \star *} \\
(0.017)\end{array}$ & $\begin{array}{l}-0.486^{\star * \star} \\
(0.072)\end{array}$ \\
\hline Healthbad & $\begin{array}{l}0.107^{\star \star \star} \\
(0.019)\end{array}$ & $\begin{array}{r}0.020 \\
(0.020)\end{array}$ & $\begin{array}{r}0.010 \\
(0.013)\end{array}$ & $\begin{array}{l}0.141^{* \star *} \\
(0.022)\end{array}$ & $\begin{array}{r}0.085 \\
(0.084)\end{array}$ \\
\hline Hours worked & $\begin{array}{c}0.008^{\star} \\
(0.005)\end{array}$ & $\begin{array}{r}0.000 \\
(0.005)\end{array}$ & $\begin{array}{r}0.002 \\
(0.002)\end{array}$ & $\begin{array}{r}0.003 \\
(0.005)\end{array}$ & $\begin{array}{r}0.011 \\
(0.018)\end{array}$ \\
\hline Self-employment & $\begin{array}{l}0.008^{\star * *} \\
(0.002)\end{array}$ & $\begin{array}{l}0.009^{\star \star \star *} \\
(0.002)\end{array}$ & $\begin{array}{r}0.000 \\
(0.001)\end{array}$ & $\begin{array}{l}0.005^{\star \star \star} \\
(0.002)\end{array}$ & $\begin{array}{l}0.032^{\star * \star} \\
(0.007)\end{array}$ \\
\hline Logged family income & $\begin{array}{r}0.016 \\
(0.015)\end{array}$ & $\begin{array}{r}0.008 \\
(0.015)\end{array}$ & $\begin{array}{r}0.001 \\
(0.006)\end{array}$ & $\begin{array}{l}-0.023^{\star} \\
(0.014)\end{array}$ & $\begin{array}{l}0.260^{\star * \star} \\
(0.068)\end{array}$ \\
\hline Unemployment income & $\begin{array}{l}0.042^{\star \star} \\
(0.019)\end{array}$ & $\begin{array}{r}0.025 \\
(0.016)\end{array}$ & $\begin{array}{l}-0.002 \\
(0.007)\end{array}$ & $\begin{array}{l}0.054^{\star \star \star} \\
(0.021)\end{array}$ & $\begin{array}{l}-0.034 \\
(0.069)\end{array}$ \\
\hline Sample size & 12,965 & 12,965 & 12,965 & 12,965 & 7,339 \\
\hline
\end{tabular}

Notes: All regressions additionally include state, year and month dummy variables. The probit model is used to estimate health care utilization and the least squares method is used to estimate logged out-of-pocket expenditures. Average marginal effects are presented in cells for the probit models. Standard errors clustered at the year and state level are shown in parentheses. ${ }^{\star \star},{ }^{\star *},{ }^{*}$ indicate statistical significance at $1 \%, 5 \%$, and $10 \%$, respectively. The reference groups are female, White, bachelor degree and above. 
Table 4: Effect of macroeconomic conditions on health care utilization and out-of-pocket expenditures using the SIPP

\begin{tabular}{|c|c|c|c|c|c|}
\hline Dependent variable & $\begin{array}{r}\text { Any medical } \\
\text { care }\end{array}$ & $\begin{array}{r}\text { Physician } \\
\text { visit }\end{array}$ & $\begin{array}{r}\text { Hospital } \\
\text { care }\end{array}$ & $\begin{array}{r}\text { Prescription } \\
\text { drug }\end{array}$ & $\begin{array}{r}\text { Out-of-pocket } \\
\text { exp. }\end{array}$ \\
\hline \multicolumn{6}{|l|}{ Macroeconomic conditions } \\
\hline $\begin{array}{l}\text { Unemployment rate (previous } 12 \\
\text { months) }\end{array}$ & $\begin{array}{l}0.010 * * \\
(0.005)\end{array}$ & $\begin{array}{l}0.015^{\star \star \star *} \\
(0.004)\end{array}$ & $\begin{array}{l}-0.007^{* *} \\
(0.003)\end{array}$ & $\begin{array}{r}0.001 \\
(0.004)\end{array}$ & $\begin{array}{l}-0.037^{\star} \\
(0.021)\end{array}$ \\
\hline State tax revenue per person & $\begin{array}{r}0.015 \\
(0.015)\end{array}$ & $\begin{array}{l}0.026^{* *} \\
(0.012)\end{array}$ & $\begin{array}{r}0.006 \\
(0.009)\end{array}$ & $\begin{array}{l}0.029 * * \\
(0.014)\end{array}$ & $\begin{array}{l}-0.012 \\
(0.072)\end{array}$ \\
\hline Wage per health care worker & $\begin{array}{r}0.003 \\
(0.002)\end{array}$ & $\begin{array}{l}-0.000 \\
(0.001)\end{array}$ & $\begin{array}{l}-0.001 \\
(0.001)\end{array}$ & $\begin{array}{r}0.001 \\
(0.001)\end{array}$ & $\begin{array}{r}0.006 \\
(0.007)\end{array}$ \\
\hline State housing price index & $\begin{array}{l}-0.037 \\
(0.044)\end{array}$ & $\begin{array}{r}0.024 \\
(0.039)\end{array}$ & $\begin{array}{r}0.005 \\
(0.025)\end{array}$ & $\begin{array}{r}0.063 \\
(0.039)\end{array}$ & $\begin{array}{l}-0.189 \\
(0.194)\end{array}$ \\
\hline Always uninsured & $\begin{array}{l}-0.060^{* * *} \\
(0.013)\end{array}$ & $\begin{array}{l}-0.173^{\star \star \star} \\
(0.012)\end{array}$ & $\begin{array}{l}-0.034^{\star \star \star} \\
(0.006)\end{array}$ & $\begin{array}{l}-0.076^{\star \star \star} \\
(0.010)\end{array}$ & $\begin{array}{r}0.054 \\
(0.068)\end{array}$ \\
\hline Sometimes uninsured & $\begin{array}{l}-0.050^{* * *} \\
(0.009)\end{array}$ & $\begin{array}{l}-0.072^{\star \star \star} \\
(0.008)\end{array}$ & $\begin{array}{l}-0.005 \\
(0.005)\end{array}$ & $\begin{array}{l}-0.036^{\star \star \star} \\
(0.007)\end{array}$ & $\begin{array}{l}-0.020 \\
(0.042)\end{array}$ \\
\hline Age & $\begin{array}{l}-0.001 \\
(0.003)\end{array}$ & $\begin{array}{r}0.001 \\
(0.003)\end{array}$ & $\begin{array}{r}0.001 \\
(0.001)\end{array}$ & $\begin{array}{l}-0.004 \\
(0.003)\end{array}$ & $\begin{array}{r}0.007 \\
(0.017)\end{array}$ \\
\hline Married & $\begin{array}{r}-0.008 \\
(0.015)\end{array}$ & $\begin{array}{r}-0.003 \\
(0.012)\end{array}$ & $\begin{array}{r}0.008 \\
(0.009)\end{array}$ & $\begin{array}{l}-0.012 \\
(0.015)\end{array}$ & $\begin{array}{r}0.046 \\
(0.069)\end{array}$ \\
\hline Have children less than 2 & $\begin{array}{l}-0.036 \\
(0.022)\end{array}$ & $\begin{array}{l}-0.046^{\star *} \\
(0.018)\end{array}$ & $\begin{array}{r}0.001 \\
(0.016)\end{array}$ & $\begin{array}{l}-0.034^{\star} \\
(0.020)\end{array}$ & $\begin{array}{r}-0.053 \\
(0.111)\end{array}$ \\
\hline Have children bet 2 and 15 & $\begin{array}{r}0.029 \\
(0.022)\end{array}$ & $\begin{array}{r}0.001 \\
(0.020)\end{array}$ & $\begin{array}{l}-0.061^{\star \star \star} \\
(0.016)\end{array}$ & $\begin{array}{l}-0.034^{\star} \\
(0.018)\end{array}$ & $\begin{array}{l}-0.325^{\star \star \star} \\
(0.098)\end{array}$ \\
\hline Education - some college & $\begin{array}{r}-0.026 \\
(0.031)\end{array}$ & $\begin{array}{r}0.039 \\
(0.027)\end{array}$ & $\begin{array}{l}-0.024^{*} \\
(0.014)\end{array}$ & $\begin{array}{r}0.023 \\
(0.028)\end{array}$ & $\begin{array}{r}-0.040 \\
(0.121)\end{array}$ \\
\hline Education - high school & $\begin{array}{l}-0.019 \\
(0.036)\end{array}$ & $\begin{array}{r}0.044 \\
(0.033)\end{array}$ & $\begin{array}{l}-0.021 \\
(0.017)\end{array}$ & $\begin{array}{c}0.053^{\star} \\
(0.032)\end{array}$ & $\begin{array}{r}0.024 \\
(0.158)\end{array}$ \\
\hline Education $-<$ high school & $\begin{array}{l}-0.039 \\
(0.038)\end{array}$ & $\begin{array}{l}0.072^{\star \star} \\
(0.034)\end{array}$ & $\begin{array}{l}-0.033^{\star} \\
(0.018)\end{array}$ & $\begin{array}{c}0.075^{\star \star} \\
(0.033)\end{array}$ & $\begin{array}{r}0.020 \\
(0.171)\end{array}$ \\
\hline Healthbad & $\begin{array}{r}-0.004 \\
(0.014)\end{array}$ & $\begin{array}{l}-0.034^{\star \star \star} \\
(0.012)\end{array}$ & $\begin{array}{l}-0.021^{\star} \\
(0.012)\end{array}$ & $\begin{array}{r}-0.008 \\
(0.013)\end{array}$ & $\begin{array}{l}-0.282^{\star \star \star} \\
(0.074)\end{array}$ \\
\hline Hours worked & $\begin{array}{l}-0.000 \\
(0.000)\end{array}$ & $\begin{array}{r}0.000 \\
(0.000)\end{array}$ & $\begin{array}{c}0.000 * \\
(0.000)\end{array}$ & $\begin{array}{r}0.000 \\
(0.000)\end{array}$ & $\begin{array}{l}0.002^{\star \star} \\
(0.001)\end{array}$ \\
\hline Self-employment & $\begin{array}{r}-0.004 \\
(0.016)\end{array}$ & $\begin{array}{r}0.004 \\
(0.014)\end{array}$ & $\begin{array}{l}-0.003 \\
(0.008)\end{array}$ & $\begin{array}{l}-0.011 \\
(0.013)\end{array}$ & $\begin{array}{l}-0.057 \\
(0.064)\end{array}$ \\
\hline Logged family income & $\begin{array}{r}0.000 \\
(0.000)\end{array}$ & $\begin{array}{l}-0.000 \\
(0.000)\end{array}$ & $\begin{array}{r}0.000 \\
(0.000)\end{array}$ & $\begin{array}{r}0.000 \\
(0.000)\end{array}$ & $\begin{array}{l}0.000^{\star \star \star *} \\
(0.000)\end{array}$ \\
\hline Unemployment income & $\begin{array}{l}-0.022^{\star \star} \\
(0.010)\end{array}$ & $\begin{array}{l}-0.024^{\star \star \star} \\
(0.008)\end{array}$ & $\begin{array}{l}-0.003 \\
(0.005)\end{array}$ & $\begin{array}{l}-0.021^{\star \star} \\
(0.009)\end{array}$ & $\begin{array}{r}0.015 \\
(0.042)\end{array}$ \\
\hline Sample size & 93,004 & 93,004 & 93,004 & 93,004 & 51,968 \\
\hline
\end{tabular}

Notes: These regressions use fixed effects linear models that control for individual fixed effects and they are adjusted using longitudinal sample weight. All regressions additionally include year and state dummy variables. Average marginal effects are presented in each cell. Standard errors clustered at the individual level are shown in parentheses. ${ }^{* \star *},{ }^{* *},{ }^{*}$ indicate statistical significance at $1 \%, 5 \%$, and $10 \%$, respectively. The reference groups are female, White, bachelor degree and above. 


\subsection{Does gender matter?}

In this subsection, we explore whether the response to macroeconomic conditions differs by gender. We examine gender differences for several reasons. First, numerous studies in the literature have documented gender differences in health care utilization. For example, Bertakis et al. (2000) find that women have a higher number of doctor visits and use more diagnostic services than men, but there is no difference in hospital utilization. They also find that the associated medical charges are higher for women. Second, men and women have different occupations that may respond differently to macroeconomic conditions. According to Hoynes, Miller, and Schaller (2012), men's jobs tend to be more pro-cyclical than women's jobs. This implies that there may be asymmetry in the utilization pattern during recessions.

Because this analysis requires individual-level data, we conduct the analysis using the SIPP. We have subsamples of 44,147 men and 48,857 women in 2008. The same regressions as in Table 4 are run for men and women separately. Results are shown in Table 5.

Table 5: Subsample analyses 2008-2011 SIPP

\begin{tabular}{lrrrrr}
\hline $\begin{array}{l}\text { Dependent } \\
\text { variable }\end{array}$ & $\begin{array}{r}\text { Any medical } \\
\text { care }\end{array}$ & $\begin{array}{r}\text { Physician } \\
\text { visit }\end{array}$ & $\begin{array}{r}\text { Hospital } \\
\text { care }\end{array}$ & $\begin{array}{r}\text { Prescription } \\
\text { drug }\end{array}$ & $\begin{array}{r}\text { Out-of-pocket } \\
\text { exp. }\end{array}$ \\
\hline Male & $N=44,147$ & & & & $N=23,380$ \\
Unemployment & $0.012^{\star}$ & $0.018^{\star \star \star}$ & $-0.007^{\star}$ & 0.004 & $-0.055^{\star}$ \\
$\quad$ rate & $(0.007)$ & $(0.007)$ & $(0.004)$ & $(0.006)$ & $(0.032)$ \\
Female & $N=48,857$ & & & & $N=28,588$ \\
Unemployment & 0.007 & $0.011^{\star \star}$ & $-0.007^{\star}$ & -0.001 & -0.022 \\
$\quad$ rate & $(0.007)$ & $(0.005)$ & $(0.004)$ & $(0.006)$ & $(0.027)$ \\
\hline
\end{tabular}

Notes: This analysis uses data from the SIPP. The regressions are fixed effects linear models at the individual level. All regressions additionally include year and state dummy variables. Marginal effects are presented in each cell. Standard errors clustered at the individual level are shown in parentheses. ${ }^{\star \star *}, * \star, *$ indicate statistical significance at $1 \%, 5 \%$, and $10 \%$, respectively. The reference groups are female, White, bachelor degree and above.

We find that when economic conditions worsen the probability of using any medical care increases for men but not for women. Examining the subcategories, a $1 \%$ increase in the unemployment rate is associated with an increase in the probability of physician visits by $1.8 \%$ points for men versus $1.1 \%$ points for women, and both men and women decrease hospital inpatient care by $0.7 \%$ point. In addition, men reduce out-of-pocket expenditures by $5.5 \%$ whereas women do not. 
These estimates suggest that the cyclical movement of health care utilization and expenditure is stronger for men than for women. This may reflect the strong response of men's employment to the business cycle. The difference in utilization pattern could also be related to eligibility criterion for welfare programs. For example, women, especially those with young children, are more likely to be eligible for public insurance (such as, Medicaid) than men.

\subsection{Does the effect of macroeconomic conditions vary by insurance status?}

During economic downturns, individuals may switch their insurance status in response to changes in employment and income. In Figure 2, we plot health insurance coverage during 2007-2010 using the CE. Uninsured households increased from about $16 \%$ in 2007 to almost $20 \%$ in 2010. Households with full coverage decreased from $76 \%$ in 2008 to about 74\% in 2010. Medicaid coverage had increased, whereas employer-provided insurance had decreased. ${ }^{19}$ The question is whether macroeconomic conditions affect insured and uninsured individuals in the same way.

To study this question, we treat insurance status as endogenous because many people change insurance status during recessions and the same characteristics (observed or unobserved) that result in a change in insurance status may also be related to medical care use. We control for the endogeneity of insurance by using a simulated measure of state Medicaid income eligibility and its interaction with health status ("healthbad") as instrumental variables (IV) in an extended TPM framework. The extended TPM has the advantage of handling both nonnormal distribution and endogeneity by additionally including a first-stage regression for the endogenous variable (Deb, Munkin, and Trivedi 2006; Du 2012).

In this framework, each household first decides whether to obtain insurance (this is the extended part, or the insurance equation), and then decide whether to use medical care and how much to use (this is the simple TPM as described earlier). Simulated Medicaid income threshold and its interaction with health status appear in the insurance equation, but do not appear in the utilization and expenditure equation. We conduct this analysis using the CE only because individual fixed effects in the SIPP absorb much of the variation in the

19 These statistics are consistent with those in the Current Population Survey and the literature (e.g. Fronstin 2011; Holahan 2011). For example, in 2009, the CPS reports that 19\% of the nonelderly population was not covered by any insurance. 

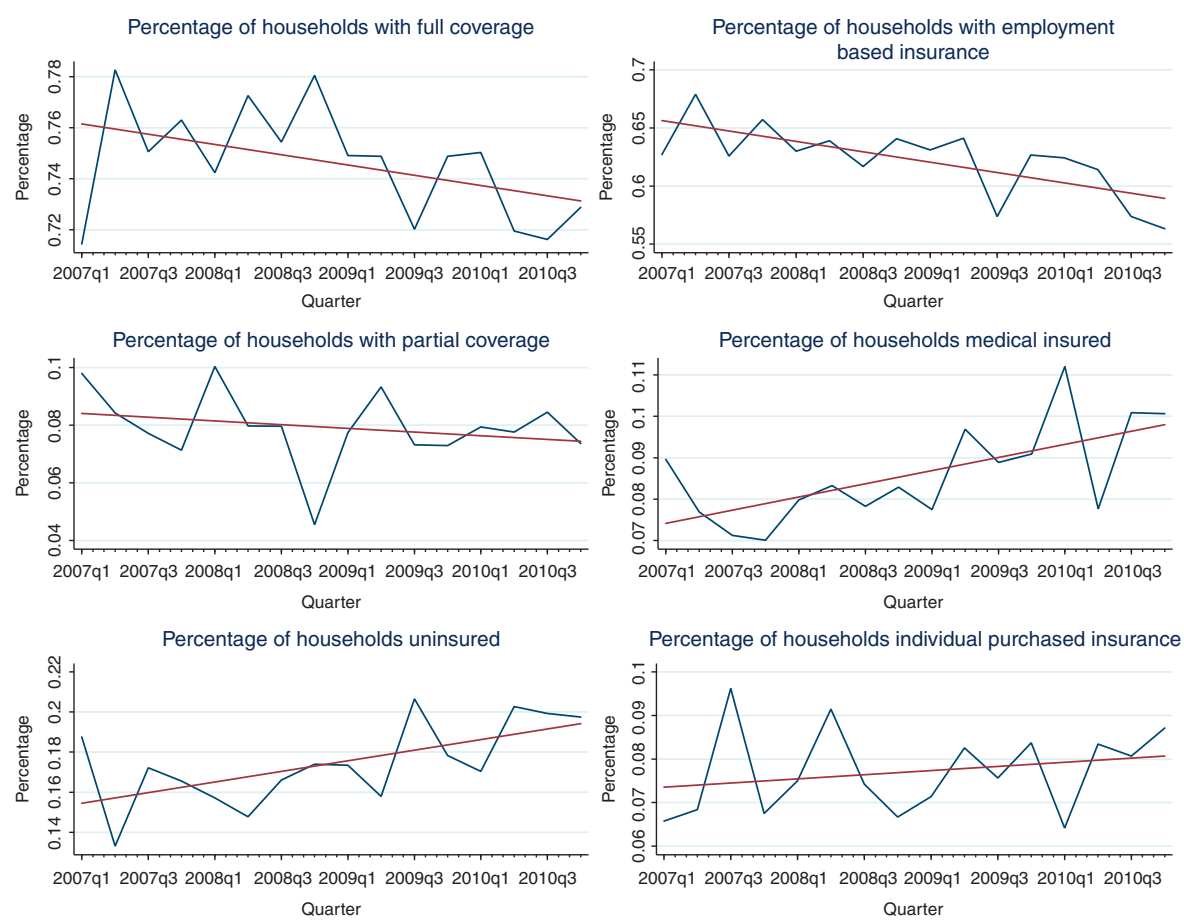

Figure 2: Insurance coverage during 2007-2010 (CE)

Note: we plot average insurance coverage at the quarterly frequency based on the CE sample. The line in each figure represents a linear trend. We observe a downward trend for full insurance coverage and employer-provided insurance, and an upward trend for uninsurance and Medicaid coverage. Individual purchased insurance exhibits a slight upward trend.

dependent variables, creating the weak instrument problem, and also because Medicaid eligibility has less variation for the sample period in the SIPP.

The generosity of state Medicaid programs is expected to affect the probability of insurance, but it is unlikely to be correlated with health care utilization. We expect insurance coverage to be positively correlated with Medicaid eligibility, though the correlation may differ by health status: a household with sick or disabled persons is more likely to enroll in Medicaid when it becomes eligible. Simulated Medicaid eligibility is constructed as the percentage of adults eligible for Medicaid in a state using the simulation approach detailed in Currie and Gruber (1996) and Ham and Shore-Sheppard (2005). By using this method, our instruments vary only with the legislative environment toward insurance at the state level. We provide details of the extended TPM, the simulation method, and the tests for IV validity in Appendix A.

We estimate health insurance decisions using the ordered probit model with full coverage treated as the most preferred outcome and uninsurance the least 
preferred. We then save the residuals from the insurance equation. In the second stage, we use the same TPM as detailed in eqs [1] and [2], with the residuals from the insurance equation as additional covariates. This residual inclusion method yields consistent estimates when the endogenous variable is nonlinear (Terza, Basu, and Rathouz 2008; Deb, Munkin, and Trivedi 2006). We can view the residuals as representing unobserved factors that influence insurance decisions (such as unobserved health status) and also affect medical care decisions.

In addition to all covariates in eqs [1] and [2], we also include interaction terms between the unemployment rate and insurance, which are used to identify whether the effect of macroeconomic conditions differs by insurance status or not.

Regression results are shown in Table 6 . We report the results using the fully insured group as the reference group in the top panel. In the bottom panel, we switch the reference group to the uninsured in order to obtain statistical inference for this group.

Table 6: Does the effect of the unemployment rate differ by insurance status? (CE sample)

\begin{tabular}{lrrrrr}
\hline $\begin{array}{l}\text { Health care } \\
\text { utilization }\end{array}$ & $\begin{array}{r}\text { Any medical } \\
\text { care }\end{array}$ & $\begin{array}{r}\text { Physician } \\
\text { visit }\end{array}$ & $\begin{array}{r}\text { Hospital } \\
\text { care }\end{array}$ & $\begin{array}{r}\text { Prescription } \\
\text { Orugs }\end{array}$ & exp.of-pocket \\
\hline
\end{tabular}

(a) Using fully insured as the reference group

$\begin{array}{lcclcr}\text { Unemployment rate } & 0.018^{\star \star *} & 0.017^{\star \star \star} & -0.004 & 0.019 * \star \star & -0.038 \\ \text { Unemp } \times \text { uninsured } & (0.005) & (0.005) & (0.003) & (0.007) & (0.023) \\ & -0.010^{\star \star} & -0.009 * \star & -0.006 * \star \star & -0.003 & 0.007 \\ \text { Unemp } \times \text { partial } & (0.004) & (0.004) & (0.002) & (0.003) & (0.019) \\ & 0.006 & 0.004 & -0.004^{\star} & 0.012^{\star \star} & -0.001 \\ & (0.005) & (0.005) & (0.002) & (0.006) & (0.018)\end{array}$

(b) Using uninsured as the reference group

\begin{tabular}{lccccc} 
Unemployment rate & 0.008 & 0.008 & $-0.009 * \star \star$ & $0.016^{\star \star}$ & -0.031 \\
Unemp $\times$ full insured & $(0.006)$ & $(0.007)$ & $(0.003)$ & $(0.007)$ & $(0.030)$ \\
& $0.010^{\star \star}$ & $0.009^{\star \star}$ & $0.006 * \star \star$ & 0.003 & -0.007 \\
Unemp $\times$ partial & $(0.004)$ & $(0.004)$ & $(0.002)$ & $(0.003)$ & $(0.019)$ \\
& $0.016^{\star \star \star}$ & $0.013^{\star \star \star}$ & 0.002 & $0.015^{\star \star \star}$ & -0.008 \\
& $(0.006)$ & $(0.005)$ & $(0.002)$ & $(0.006)$ & $(0.026)$ \\
\hline
\end{tabular}

Notes: (1) Each regression additionally controls for household variables in Table 3, other macroeconomic variables, and state, year, and month dummy variables. Standard errors clustered at the year and the state level are presented in parentheses. ***, **, * indicate statistical significance at $1 \%, 5 \%$, and $10 \%$, respectively. (2) In these regressions, insurance variables (uninsured and partial insured) are treated as endogenous variables. We use simulated state Medicaid income eligibility and its interaction with healthbad as instruments. The first stage uses the Ordered Probit model to predict three insurance outcomes (uninsured, partial, and full insurance). We then use the first-stage residuals as additional regressors to predict health care utilization and out-of-pocket expenditures in the second stage. 
The negative coefficients of the interaction terms indicate that the effect of the unemployment rate for the uninsured is smaller than that for the fully insured households. For overall utilization, the coefficient for the insured is 0.018 (top panel) and significant at $1 \%$, whereas the coefficient for the uninsured is 0.008 (bottom panel) and is not statistically significant. This indicates that uninsured households do not increase overall utilization as much as the insured.

When breaking down by subcategories, we find that the probability of using hospital care is unaffected for the insured, but decreases (0.9\% point) for the uninsured when macroeconomic conditions worsen. The insured group is more likely to visit a physician, and both the insured and the uninsured households are more likely to use prescription drugs as the unemployment rate rises.

\section{Comparison with the pre-recession period}

In this section, we examine whether the relationship between macroeconomic conditions and health care utilization is unique to the Great Recession or whether this relationship also existed before the recession.

Several papers point out some unique aspects of the Great Recession. For example, Tekin, McClellan, and Minyard (2013) find no statistically significant relationship between the business cycle and health during the Great Recession, which is in contrast to Ruhm's result of counter-cyclical health using earlier data. Using data that encompasses part of the Great Recession, McInerney and Mellor (2012) report that the senior mortality rate is counter-cyclical, as opposed to the procyclical mortality reported by earlier studies. They speculate that the relationship between unemployment and health may have changed in more recent years.

To check whether the relationship between macroeconomic conditions and health care utilization has changed, we extend our data to 4 years before the Great Recession. In particular, data from January 2003 to December 2006 in the CE and the 2004 panel of the SIPP are used. Health care utilization variables are again obtained from the topical module of the SIPP, which is only available in interview waves 3 and $6 .^{20}$ The sample period in the SIPP based on utilization is August 2003-2005. In the pre-recession period, the sample size for the CE is 14,914 households and for the SIPP it is 88,556 observations or 45,401 individuals.

Regressions for the pre-recession period and the entire sample period are run and results are shown in Table 7 . In the CE, we find no statistically significant relationship between unemployment, health care utilization, and out-of-pocket expenditures in the pre-recession period. For the SIPP, we find a

20 Due to funding cut, the topical module scheduled for wave 9 was cancelled. 


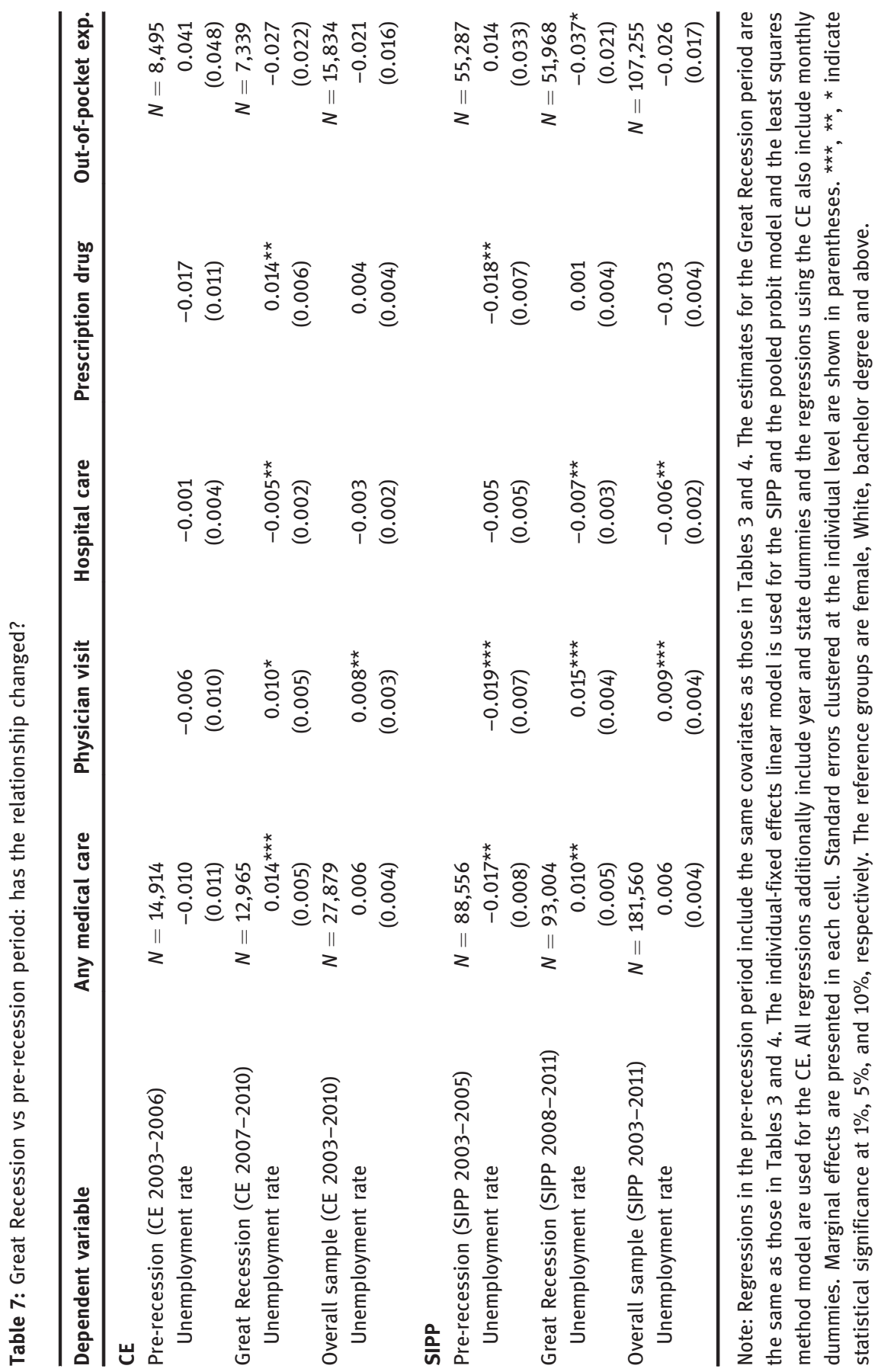


negative association between the unemployment rate and several categories of utilization. Specifically, overall medical use, physician visits, and prescription drug use decrease as the unemployment rate rises. This indicates that health care utilization is somewhat pro-cyclical or acyclical in the pre-recession period, in contrast to what we find during the Great Recession.

For the longer sample, we find that unemployment is associated with more physician visits in both datasets, but we do not find statistically significant relationship for the other outcome variables.

\section{Does "frequency" matter?}

Despite the differences in interview frequency, unit of observation, and estimation method, the results are surprisingly similar across the CE and the SIPP. In this subsection, we explore whether it is worthwhile to use a higher-frequency data and whether frequency of observation matters.

We use the CE for this exercise because we want to ensure the differences in estimates are only caused by frequency rather than by other factors. Specifically, we construct annual-frequency variables instead of quarterly-frequency variables from the CE. For example, our new dependent variable is annual expenditures on medical care, which combines the health care expenditures of the same household in all four quarters. Recall that the same household may appear a maximum of four times in the survey and in original regressions only the second wave is used. Macroeconomic variables are constructed to match the timing of the annual-frequency variables.

Due to sample attrition (not all households appear in all four quarters), the sample size of this new sample is 7,330, smaller than the original sample $(N=$ 12,965). To make sure results are comparable, we ran the original regressions with this smaller sample that consists of households appearing four times in the survey. Both the longer sample (2003-2010) and the Great Recession (2007-2010) period are examined and results are shown in Table 8.

Although the differences in estimates between the annual- and quarterlyfrequency data are not particularly obvious in the longer sample (partly because of statistically insignificant coefficients), we do observe a sharp contrast during the Great Recession. For the annual-frequency sample, the unemployment rate is not statistically significant for any utilization variables; the unemployment rate has a statistically significant and negative impact on out-of-pocket expenditures. Recall that the unemployment rate was statistically significant for three of the four utilization outcomes (overall use, physician visits, and prescription drug us) when we use quarterly-frequency variables. 
Table 8: Quarterly vs annual-frequency data (CE sample)

\begin{tabular}{|c|c|c|c|c|c|}
\hline Dependent variable & $\begin{array}{r}\text { Any medical } \\
\text { care }\end{array}$ & $\begin{array}{r}\text { Physician } \\
\text { visit }\end{array}$ & $\begin{array}{r}\text { Hospital } \\
\text { care }\end{array}$ & $\begin{array}{r}\text { Prescription } \\
\text { drug }\end{array}$ & $\begin{array}{r}\text { Out-of-pocket } \\
\text { exp. }\end{array}$ \\
\hline \multicolumn{6}{|c|}{ CE 2007-2010 (Great Recession) } \\
\hline Annual frequency & $N=7,330$ & & & & $N=6,083$ \\
\hline Unemployment rate & $\begin{array}{l}0.0003 \\
(0.006)\end{array}$ & $\begin{array}{r}0.001 \\
(0.009)\end{array}$ & $\begin{array}{r}-0.0002 \\
(0.006)\end{array}$ & $\begin{array}{r}0.007 \\
(0.009)\end{array}$ & $\begin{array}{l}-0.069^{\star \star} \\
(0.029)\end{array}$ \\
\hline Quarterly frequency & $N=7,330$ & & & & $N=4,523$ \\
\hline Unemployment rate & $\begin{array}{l}0.017^{\star \star \star} \\
(0.006)\end{array}$ & $\begin{array}{l}0.018^{\star \star \star} \\
(0.007)\end{array}$ & $\begin{array}{l}-0.002 \\
(0.003)\end{array}$ & $\begin{array}{c}0.016^{\star \star} \\
(0.008)\end{array}$ & $\begin{array}{l}-0.024 \\
(0.032)\end{array}$ \\
\hline \multicolumn{6}{|l|}{ CE 2003-2010 (Overall) } \\
\hline Annual frequency & $N=16,761$ & & & & $N=13,920$ \\
\hline Unemployment rate & $\begin{array}{l}-0.001 \\
(0.005)\end{array}$ & $\begin{array}{c}0.009^{\star} \\
(0.005)\end{array}$ & $\begin{array}{l}0.0003 \\
(0.005)\end{array}$ & $\begin{array}{c}0.009^{\star} \\
(0.006)\end{array}$ & $\begin{array}{r}0.008 \\
(0.021)\end{array}$ \\
\hline Quarterly frequency & $N=16,761$ & & & & $N=10,335$ \\
\hline Unemployment rate & $\begin{array}{r}0.009 \\
(0.005)\end{array}$ & $\begin{array}{l}0.009^{\star *} \\
(0.004)\end{array}$ & $\begin{array}{l}-0.003 \\
(0.002)\end{array}$ & $\begin{array}{r}0.006 \\
(0.006)\end{array}$ & $\begin{array}{r}-0.0140 \\
(0.022)\end{array}$ \\
\hline
\end{tabular}

Notes: Both annual- and quarterly-frequency samples are from the CE. Specifically, we construct health care expenditures and utilization variables at the annual frequency as opposed to the quarterly frequency variables used in original regressions. To construct annual-frequency data, we dropped households that did not appear in all interview waves, thus the sample size is smaller. To make results comparable, we re-ran the regression in Table 3 with this smaller sample.

This exercise shows that frequency does matter and that using annual-frequency data may not capture the contemporaneous relationships between the macroeconomy and health care variables.

\section{Sensitivity analysis}

We conduct additional analysis to check the robustness of our main results.

First, there are several variables that potentially stand in the causal pathway from macroeconomic conditions to health care utilization and expenditures. For example, when macroeconomic conditions worsen, people may lose their jobs and employer-provided insurance, which may in turn affect utilization and expenditures. We examine whether our estimation results are sensitive to the exclusion of such variables by exploring several alternative specifications: Model 1 excludes employment, income, insurance, and other macroeconomic variables; Model 2 excludes insurance and other macroeconomic variables; Model 3 excludes other macroeconomic variables. Results are presented in Table 9 and the original baseline model estimates are shown in the last column for comparison. 
Table 9: Sensitivity analyses with alternative model specifications

\begin{tabular}{|c|c|c|c|c|}
\hline \multirow[t]{2}{*}{ Dependent variable } & Model 1 & Model 2 & Model 3 & \multirow{2}{*}{$\begin{array}{r}\text { Model } 4 \\
\text { (Baseline) }\end{array}$} \\
\hline & $\begin{array}{l}\text { Excludes emp., } \\
\text { income, insurance, } \\
\text { other macro vars }\end{array}$ & $\begin{array}{r}\text { Excludes } \\
\text { insurance, other } \\
\text { macro vars }\end{array}$ & $\begin{array}{r}\text { Excludes } \\
\text { other macro } \\
\text { vars }\end{array}$ & \\
\hline \multicolumn{5}{|l|}{ CE 2007-2010 } \\
\hline Any medical care & $\begin{array}{c}0.010^{\star *} \\
(0.004)\end{array}$ & $\begin{array}{l}0.010^{\star \star \star} \\
(0.004)\end{array}$ & $\begin{array}{l}0.013^{* \star *} \\
(0.004)\end{array}$ & $\begin{array}{l}0.014^{\star \star \star} \\
(0.005)\end{array}$ \\
\hline Physician visit & $\begin{array}{c}0.007^{\star} \\
(0.004)\end{array}$ & $\begin{array}{l}0.008^{\star \star} \\
(0.004)\end{array}$ & $\begin{array}{l}0.009^{\star \star} \\
(0.004)\end{array}$ & $\begin{array}{c}0.010^{\star} \\
(0.005)\end{array}$ \\
\hline Hospital care & $\begin{array}{l}-0.004^{\star \star} \\
(0.002)\end{array}$ & $\begin{array}{l}-0.004^{\star \star} \\
(0.002)\end{array}$ & $\begin{array}{l}-0.003^{\star} \\
(0.002)\end{array}$ & $\begin{array}{l}-0.005^{\star \star} \\
(0.002)\end{array}$ \\
\hline Pres. drugs & $\begin{array}{l}0.013^{\star \star \star} \\
(0.004)\end{array}$ & $\begin{array}{l}0.013^{\star \star \star} \\
(0.004)\end{array}$ & $\begin{array}{l}0.015^{\star \star \star} \\
(0.004)\end{array}$ & $\begin{array}{l}0.014^{\star \star} \\
(0.006)\end{array}$ \\
\hline Out-of-pocket exp. & $\begin{array}{l}-0.029 \\
(0.017)\end{array}$ & $\begin{array}{l}-0.025 \\
(0.017)\end{array}$ & $\begin{array}{l}-0.026 \\
(0.017)\end{array}$ & $\begin{array}{l}-0.027 \\
(0.022)\end{array}$ \\
\hline \multicolumn{5}{|l|}{ SIPP 2008-2011 } \\
\hline Any medical care & $\begin{array}{l}0.013^{\star \star \star} \\
(0.004)\end{array}$ & $\begin{array}{l}0.014^{\star \star \star} \\
(0.004)\end{array}$ & $\begin{array}{l}0.014^{\star \star \star} \\
(0.004)\end{array}$ & $\begin{array}{l}0.010^{\star \star} \\
(0.005)\end{array}$ \\
\hline Physician visit & $\begin{array}{l}0.012^{\star \star \star} \\
(0.004)\end{array}$ & $\begin{array}{l}0.013^{\star \star \star *} \\
(0.004)\end{array}$ & $\begin{array}{l}0.013^{\star * *} \\
(0.004)\end{array}$ & $\begin{array}{l}0.015^{\star *} \\
(0.004)\end{array}$ \\
\hline Hospital care & $\begin{array}{l}-0.008^{\star \star \star} \\
(0.003)\end{array}$ & $\begin{array}{l}-0.008^{\star \star \star} \\
(0.003)\end{array}$ & $\begin{array}{l}-0.008^{\star \star \star} \\
(0.003)\end{array}$ & $\begin{array}{l}-0.007^{\star *} \\
(0.003)\end{array}$ \\
\hline Pres. drugs & $\begin{array}{r}0.000 \\
(0.004)\end{array}$ & $\begin{array}{r}0.000 \\
(0.004)\end{array}$ & $\begin{array}{r}0.001 \\
(0.004)\end{array}$ & $\begin{array}{r}0.001 \\
(0.004)\end{array}$ \\
\hline Out-of-pocket exp. & $\begin{array}{l}-0.024 \\
(0.018)\end{array}$ & $\begin{array}{l}-0.025 \\
(0.018)\end{array}$ & $\begin{array}{l}-0.025 \\
(0.018)\end{array}$ & $\begin{array}{l}-0.037^{\star} \\
(0.021)\end{array}$ \\
\hline
\end{tabular}

Notes: Marginal effects of the unemployment rate are shown in cells with standard errors in parentheses. Model 1 is the simple model that excludes employment, income, insurance, and other macroeconomic variables. Model 2 excludes insurance and other macroeconomic variables. Model 3 excludes other macroeconomic variables. Model 4 is the baseline model that is presented in Tables 3 and 4. ${ }^{\star \star *},{ }^{\star *}$, * indicate statistical significance at $1 \%, 5 \%$, and $10 \%$, respectively.

The estimates for the unemployment rate in the CE and the SIPP fluctuate little across the four models. For example, the marginal effect ranges between 1.0\% and $1.4 \%$ points for any medical care. For physician visits, the marginal effect ranges between $1.2 \%$ and $1.5 \%$ points in the SIPP and $0.7 \%$ and $1.0 \%$ points in the CE. For hospital care, the marginal effect ranges between $-0.7 \%$ and $-0.8 \%$ point in the SIPP and $-0.3 \%$ and $-0.5 \%$ point in the CE. All the estimates are statistically significant. 
Second, in our main analysis, we used positive expenditure to indicate utilization. There are a small number of individuals that used care but did not incur any expense. We use the SIPP to examine whether the effect of macroeconomic conditions differs for the subsample that incurred positive expenditures and the subsample that used care (but may or may not incur an expense). We find that the effect of the unemployment rate on overall use of medical care is slightly larger for the sample that incurred positive expenditures (0.010 vs 0.008). This is expected because business fluctuations would not matter much for those who did not have to pay for care.

Third, some observations in the CE are dropped from our analysis because state information are either suppressed or recoded. To ensure the sample used for analysis does not suffer from selection bias, we examine summary statistics for this state-missing subsample with the sample used in our analysis, and then perform additional regressions that incorporate this state-missing subsample. The summary statistics for this subsample are shown in Appendix B, Table 11. Compared with the sample without state missing, the state-missing subsample has a higher percentage of households without insurance and a lower percentage of households visiting physicians. We find that when including the statemissing subsample, the effect of the unemployment rate does not differ much (see Appendix B, Table 12). This suggests that omitting the state-missing subsample is unlikely to cause selection bias.

\section{Conclusions}

In this paper, we study the impact of the business cycle on health care utilization and out-of-pocket expenditures during the Great Recession. We use two data sources to conduct our analysis and each has its own strengths.

The results consistent across the two datasets are summarized as follows. We find that overall health care utilization was counter-cyclical during the Great Recession, and the effect of the unemployment rate differed by type of care. Routine health care, such as physician visits, was counter-cyclical, whereas nonroutine health care, such as hospital care, was pro-cyclical. These results are consistent with the evidence in the literature that suggests time cost is an important factor for the use of routine health care services ( $\mathrm{Xu}$ 2013; Vistnes and Hamilton 1995).

One of the inconsistent results between the CE and the SIPP is that prescription drug use increased in the CE, but did not in the SIPP as the unemployment rate rose. Since the CE measures utilization at the quarterly frequency and the 
SIPP at the annual frequency, this result might suggest that the short-run response to the increase in the unemployment rate was to consume more drugs, whereas in the long run people were more likely to visit doctors (the marginal effect for physician visits in the SIPP was larger than that in the CE).

We show that the effect of the macroeconomy was not uniform. Men responded more strongly to the business cycle than women did. This may be due to gender differences in job cyclicality and the eligibility criteria of welfare programs. We also show that as the unemployment rate rose, the probability of using any medical care increased much more for the insured than for the uninsured. The insured households were more likely to use physician visits; whereas the uninsured households were more likely to use prescription drugs; they reduced hospital visits much more than the insured.

An interesting question is whether the relationship between the macroeconomy and health care utilization was unique during the Great Recession. We examined this relationship during the pre-recession period, but failed to find statistically significant estimates in the CE, while the evidence in the SIPP suggested that routine health care is somewhat pro-cyclical. This result suggests that the Great Recession period is different from the pre-recession period. However, we cannot tell whether the Great Recession has changed people's behaviors permanently. This result may simply reflect the magnitude of the shock during the Great Recession.

Our research points to the importance of using higher-frequency data to analyze health-related outcomes. As we show, the effect of macroeconomic conditions may not be well captured in annual-frequency data. Future empirical work on business cycles and health would benefit greatly from the collection of higher-frequency health data.

Our results that medical care use fluctuates with the business cycle have important policy implications on how resources should be allocated during recessions to improve access to care and maintain public health. In the United States, a large proportion of health care spending is on chronic conditions. Because insurance coverage is closely tied to employment status, the fluctuation of macroeconomic conditions and insurance coverage prevents patients with chronic conditions from accessing adequate medical care and thus contributes to a failure to maintain a stable health status (McWilliams 2009). This may also reduce insurers' incentives to provide preventive care that has long-term health benefits. Sensible health policies should aim at reducing the fluctuation of health care utilization and better allocating resources to improve health care access in society.

Since both the CE and SIPP are collected from household interviews, information on overall health care expenditures is not available. Thus, we cannot answer the bigger question as to whether the Great Recession has played any 
role in the slowdown in overall health care expenditures. In addition, we did not compare the Great Recession with recessions in the past; thus, we are not able to explore the question of whether people's behavior has changed over a long time span. These topics are worth investigating in future research.

\section{Appendix A: An extended two-part model}

In the first stage, we model insurance decisions as the following,

$$
\begin{aligned}
& I_{\text {ist }}{ }^{*}=\delta_{1} x_{i s t}+\delta_{2} z_{s t}+\delta_{3} \text { Elig }_{s t}+\delta_{4} \text { Elig }_{s t} * \text { healthbad }{ }_{\text {ist }}+\omega_{s}+\theta_{t}+v_{\text {ist }} \\
& i=1 \ldots, N(\text { households }), s=1, \ldots, S(\text { state }), t=1, \ldots, T(\text { time }) \\
& I=\left\{\begin{array}{rr}
1 & \text { uninsurance } \\
2 & \text { partialinsurance } \\
3 & \text { full insurance }
\end{array}\right.
\end{aligned}
$$

where $I^{*}$ is a latent variable indicating the utility of being insured. When $I^{*}$ crosses a series of unknown thresholds, we move up the ordering of choices. $x$ is a set of household demographic and socio-economic variables and $z$ is a set of state-level variables that represent macroeconomic conditions. Elig is a "simulated eligibility" measure that indicates the generosity of state Medicaid program. We also include an interaction term (Elig * healthbad), in which healthbad is a dummy variable that equals 1 if either the reference person or the spouse did not work in the previous 12 months due to illness or disability. The eligibility variable and the interaction term are the exclusive restrictions that are included in the insurance equation and excluded from the health care equations. Year and month fixed effects $\left(\theta_{t}\right)$ are included to control for the common shocks that occur in a particular month and year. State fixed effects $\left(\omega_{s}\right)$ are used to control for the time-invariant factors unique to each state. The error term $(v)$ conditional on independent variables is assumed to follow a standard normal distribution.

In the second stage, we use a two-part model for health care utilization (Duan et al. 1983). The first part estimates the probability of using care (utilization equation) and the second part estimates expenditure conditional on use (expenditure equation). Specifically, the two parts can be written as

$$
\begin{aligned}
\operatorname{Pr}\left(H_{i s t, c}>0\right)= & \beta_{1} x_{i s t}+\beta_{2} I_{i s t}^{u}+\beta_{3} I_{i s t}^{p}+\beta_{4} z_{s t}+\beta_{5} I_{i s t}^{u} z_{s t}+\beta_{6} I_{i s t}^{p} z_{s t}+\tau_{1} v_{1, i s t} \\
& +\tau_{2} v_{2, i s t}+\omega_{s}+\theta_{t}+\epsilon_{1, i s t, c}
\end{aligned}
$$




$$
\begin{aligned}
\ln \left(H_{\text {ist }, c}\right) \mid\left(H_{\text {ist }, c}>0\right)= & \beta_{7} x_{i s t}+\beta_{8} I_{i s t}^{u}+\beta_{9} I_{i s t}^{p}+\beta_{10} z_{s t}+\beta_{11} I_{i s t}^{u} z_{s t}+\beta_{12} I_{i s t}^{p} z_{s t} \\
& +\tau_{3} v_{1, i s t}+\tau_{4} v_{2, i s t}+\omega_{s}+\theta_{t}+\epsilon_{2, i s t, c},
\end{aligned}
$$

where eq. [4] is the utilization equation (estimated by the probit model) and eq. [5] is the expenditure equation (estimated by the least squares method). $H$ is out-of-pocket health care expenditure for individual households. The subscript $c$ indicates the three types of health care use (physician visits, hospital, and prescription drugs). In both eqs [4] and [5], we include the predicted residuals from eq. [3] as additional variables. The residuals are defined as $v_{1}=I^{u}-\widehat{I}^{u}$ and $v_{2}=I^{p}-\widehat{I^{p}}$, where $I^{u}$ and $I^{p}$ are dummy variables indicating uninsurance and partial insurance and $\widehat{I^{u}}$ and $\widehat{I^{p}}$ are the predicted probabilities for uninsurance and partial insurance from eq. [3].

We construct percentage eligible using the simulation approach detailed in Currie and Gruber (1996) and Ham and Shore-Sheppard (2005). That is, we use all CE households with children ${ }^{21}$ except for the households from the state that the eligibility is being imputed, and then determine the eligibility for Medicaid by comparing household income with the eligibility threshold in that state. If a household's income is less than the threshold dollar amount, ${ }^{22}$ the household is regarded as Medicaid eligible. We use adults' eligibility (rather than children's eligibility) because eligibility thresholds for children were the same for many states during our sample period and eligibility thresholds for adults had more variations. ${ }^{23}$ The mean percentage of adults eligible for Medicaid in our sample is $11.8 \%$.

By using the simulation method, our instruments vary only with the legislative environment toward insurance at the state level, thus they are uncorrelated with the errors in the health care expenditure equations, assuming that the instruments are not correlated with other macroeconomic variables that could potentially affect utilization. We include state dummy variables to control for state-level variables that do not change over time. We also control for additional time-varying macroeconomic variables to reduce potential omitted variable bias at the state level.

Results for the first-stage regression are shown in Table 10. We find that a $1 \%$ point increase in the state unemployment rate is associated with a $1.0 \%$ point

21 Adults without dependent children are generally excluded from Medicaid.

22 The income eligibility threshold is often measured in terms of percentage of the federal poverty line. Because the poverty line differs by family size, the eligibility income limit also differs by family size when it is converted into a dollar amount.

23 The eligibility thresholds are obtained from the Kaiser Family Foundation website and they differ for working and nonworking adults. This is because some labor income can be excluded when calculating Medicaid eligibility. 
Table 10: First-stage regressions (dependent variables are insurance status)

\begin{tabular}{|c|c|c|c|}
\hline Dependent variable & Uninsurance & Partial insurance & Full insurance \\
\hline Unemployment rate & $\begin{array}{l}0.010^{\star \star} \\
(0.005)\end{array}$ & $\begin{array}{l}0.003^{\star \star} \\
(0.001)\end{array}$ & $\begin{array}{l}-0.013^{\star \star} \\
(0.006)\end{array}$ \\
\hline Medicaid eligibility & $\begin{array}{l}-0.208^{\star * *} \\
(0.064)\end{array}$ & $\begin{array}{l}-0.052^{\star \star \star} \\
(0.016)\end{array}$ & 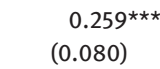 \\
\hline Medicaid eligibility $\times$ healthbad & $\begin{array}{l}-0.203 \\
(0.160)\end{array}$ & $\begin{array}{l}-0.050 \\
(0.039)\end{array}$ & $\begin{array}{r}0.254 \\
(0.200)\end{array}$ \\
\hline State tax revenue per person & $\begin{array}{l}-0.007^{\star \star} \\
(0.003)\end{array}$ & $\begin{array}{l}-0.002^{\star \star} \\
(0.001)\end{array}$ & $\begin{array}{l}0.008^{\star \star} \\
(0.004)\end{array}$ \\
\hline Wage per health care worker & $\begin{array}{r}0.002 \\
(0.001)\end{array}$ & $\begin{array}{r}0.000 \\
(0.000)\end{array}$ & $\begin{array}{l}-0.002 \\
(0.002)\end{array}$ \\
\hline State housing price index & $\begin{array}{r}0.007 \\
(0.022)\end{array}$ & $\begin{array}{r}0.002 \\
(0.005)\end{array}$ & $\begin{array}{l}-0.009 \\
(0.027)\end{array}$ \\
\hline Age (of reference person) & $\begin{array}{l}-0.003^{\star * *} \\
(0.000)\end{array}$ & $\begin{array}{l}-0.001^{\star \star \star} \\
(0.000)\end{array}$ & $\begin{array}{l}0.004^{\star \star \star *} \\
(0.000)\end{array}$ \\
\hline Male & $\begin{array}{l}0.036^{\star * *} \\
(0.006)\end{array}$ & $\begin{array}{l}0.009^{\star \star \star} \\
(0.002)\end{array}$ & $\begin{array}{l}-0.045^{\text {} \star \star \star ~} \\
(0.008)\end{array}$ \\
\hline African American & $\begin{array}{l}0.052^{\star \star \star} \\
(0.011)\end{array}$ & $\begin{array}{l}0.012^{\star \star \star} \\
(0.002)\end{array}$ & $\begin{array}{l}-0.063^{\star \star \star} \\
(0.013)\end{array}$ \\
\hline Non-white Hispanic & $\begin{array}{l}0.108^{\star \star \star} \\
(0.010)\end{array}$ & $\begin{array}{l}0.022^{\star \star \star} \\
(0.002)\end{array}$ & $\begin{array}{l}-0.130^{\star \star \star} \\
(0.012)\end{array}$ \\
\hline Other races & $\begin{array}{l}0.039 * \star \star \\
(0.011)\end{array}$ & $\begin{array}{l}0.009^{\star \star \star} \\
(0.002)\end{array}$ & $\begin{array}{l}-0.048^{\star \star \star} \\
(0.013)\end{array}$ \\
\hline Married & $\begin{array}{l}-0.023^{\star \star \star} \\
(0.006)\end{array}$ & $\begin{array}{l}-0.006^{\star \star \star} \\
(0.002)\end{array}$ & $\begin{array}{l}0.029^{\star \star \star *} \\
(0.008)\end{array}$ \\
\hline No. of children less than 2 & $\begin{array}{l}-0.054^{\star \star \star} \\
(0.012)\end{array}$ & $\begin{array}{l}-0.013^{\star * *} \\
(0.003)\end{array}$ & $\begin{array}{l}0.067^{\star \star \star *} \\
(0.014)\end{array}$ \\
\hline No. of children bet 2 and 15 & $\begin{array}{l}-0.020^{\star \star \star} \\
(0.003)\end{array}$ & $\begin{array}{l}-0.005^{\star \star \star} \\
(0.001)\end{array}$ & $\begin{array}{l}0.025^{\star \star \star} \\
(0.004)\end{array}$ \\
\hline Education - some college & $\begin{array}{l}0.051^{\star \star \star} \\
(0.010)\end{array}$ & $\begin{array}{l}0.012^{\star \star \star} \\
(0.003)\end{array}$ & $\begin{array}{l}-0.064^{\star \star \star} \\
(0.013)\end{array}$ \\
\hline Education - high school & $\begin{array}{l}0.127^{\star \star \star} \\
(0.015)\end{array}$ & $\begin{array}{l}0.026^{\star \star \star} \\
(0.003)\end{array}$ & $\begin{array}{l}-0.153^{\star \star \star} \\
(0.017)\end{array}$ \\
\hline Education - less than high school & $\begin{array}{l}0.181^{\star \star *} \\
(0.018)\end{array}$ & $\begin{array}{l}0.031^{\star \star *} \\
(0.002)\end{array}$ & $\begin{array}{l}-0.211^{\text {***}} \\
(0.020)\end{array}$ \\
\hline Healthbad & $\begin{array}{l}-0.016 \\
(0.019)\end{array}$ & $\begin{array}{l}-0.004 \\
(0.005)\end{array}$ & $\begin{array}{r}0.020 \\
(0.024)\end{array}$ \\
\hline Hours worked & $\begin{array}{l}-0.023^{\star \star \star} \\
(0.003)\end{array}$ & $\begin{array}{l}-0.006^{\star \star \star} \\
(0.001)\end{array}$ & $\begin{array}{l}0.029^{\star \star \star} \\
(0.004)\end{array}$ \\
\hline Salary income & $\begin{array}{l}-0.005^{\star \star \star} \\
(0.001)\end{array}$ & $\begin{array}{l}-0.001^{\star \star \star} \\
(0.000)\end{array}$ & $\begin{array}{l}0.006^{\star \star \star *} \\
(0.002)\end{array}$ \\
\hline Self-employed & $\begin{array}{l}0.088^{\star \star \star} \\
(0.011)\end{array}$ & $\begin{array}{l}0.022^{\star \star \star} \\
(0.003)\end{array}$ & $\begin{array}{l}-0.110^{\star \star \star} \\
(0.014)\end{array}$ \\
\hline
\end{tabular}

Note: Sample size is 12,965 . The Ordered Probit model is used in estimation. Insurance status is ranked using full insurance as the most referred outcome and uninsured as the least preferred outcome. State, year, and month fixed effects are included. Marginal effects are presented in each cell. Standard errors clustered at the year and state level are included in parentheses. $* \star *, * \star$, * indicate statistical significance at $1 \%, 5 \%$, and $10 \%$, respectively. 
increase in the probability of losing coverage and a $0.3 \%$ point increase in the probability of becoming partially insured. Our estimates are similar to the estimates in Cawley, Moriya, and Simon (2011).

We also perform several tests to check the validity of our instruments. Based on the first-stage regression (Table 10), Medicaid eligibility reduces the probability of uninsurance and partial insurance and increases the probability of full insurance. The interaction between Medicaid eligibility and healthbad is positive, indicating the effect of Medicaid eligibility is stronger for those with disability or illness. The two instruments pass the weak identification test with a Wald F-statistics of 19.34 for the overall sample. Stock, Wright, and Yogo (2002) show that a F-statistics larger than 10 is generally acceptable for IV estimation. The Hansen $J$ test yields a $p$-value of 0.82 , indicating that the instruments are neither correlated with the error terms nor correlated with the dependent variables in the health care equations.

Finally, we perform hypothesis tests to examine whether insurance is endogenous $\left(H_{0}: v_{1}=v_{2}=0\right)$. Rejection of the null hypothesis $\left(H_{0}: v_{1}=v_{2}=0\right)$ indicates that the insurance variables may be correlated with the error terms. We reject the null hypothesis in several cases and fail to reject in others. The rejection occurs for physician visit and prescription drug use. This suggests that there may be unobserved factors at the household level (e.g. unobserved health conditions) that affect physician visits and prescription drug use.

\section{Appendix B: Including the sample with missing state information in the CE}

Five states are not included in the CE, and they are Iowa, New Mexico, North Dakota, Vermont, and Wyoming. Seven states have state information entirely suppressed, and they are Arkansas, Mississippi, Montana, North Carolina, Oklahoma, Rhode Island, and South Dakota. ${ }^{24}$ Six states include households whose state information is recoded, and they are Alabama, Delaware, Georgia, Maryland, Minnesota, and Wisconsin. In total, we have 18 states not included in our main analysis and 13 states are excluded because of missing or recoded state information (3,989 observations). Among the 3,989 observations, 1,652 observations are recoded and 2,337 observations have state information suppressed.

24 It was unclear whether Oklahoma and Rhode Island were not included in the interview or had their state information suppressed. In the CE document, the two states were listed, but we could not find them in the data file. 
We provide summary statistics for those with and without state missing or recoded in Table 11. On average, the sample without state missing has a slightly lower uninsurance rate (18\% vs $20 \%$ ) and a higher percentage of physician visits (31\% vs 27\%) and greater out-of-pocket expenditures (\$294 vs \$268). In terms of demographic characteristics, the sample without state missing is older, consisting of fewer African American, more Hispanic, more in marriage (61\% vs 54\%), having more children ( 0.61 vs 0.54$)$, and better educated. They also work longer hours and have higher household salary.

Table 11: Sample comparison

\begin{tabular}{|c|c|c|}
\hline \multirow[t]{2}{*}{ Variable } & $\begin{array}{r}\text { Sample without } \\
\text { state missing (1) }\end{array}$ & $\begin{array}{r}\text { Sample with state } \\
\text { missing (2) }\end{array}$ \\
\hline & Mean (st. dev) & Mean (st. dev) \\
\hline Sample size & 12,965 & 3,989 \\
\hline Uninsurance & $0.18(0.38)$ & $0.20(0.40)$ \\
\hline Partial insurance & $0.08(0.27)$ & $0.08(0.28)$ \\
\hline Full insurance & $0.74(0.44)$ & $0.72(0.45)$ \\
\hline Any medical care & $0.56(0.50)$ & $0.56(0.50)$ \\
\hline Any physician visit & $0.31(0.46)$ & $0.27(0.44)$ \\
\hline Any prescription drugs & $0.37(0.48)$ & $0.39(0.49)$ \\
\hline Any hospital care & $0.05(0.21)$ & $0.05(0.22)$ \\
\hline Overall out-of-pocket expenditure (OOP) & $294.41(734.05)$ & $267.55(613.74)$ \\
\hline Physician visit OOP & $52.72(191.27)$ & $45.42(170.91)$ \\
\hline Drug OOP & $72.57(229.95)$ & $73.68(209.09)$ \\
\hline Hospital OOP & $30.86(281.63)$ & $26.82(210.55)$ \\
\hline Age & $42.91(11.80)$ & $42.05(12.86)$ \\
\hline Gender $($ male $=1)$ & $0.50(0.50)$ & $0.50(0.50)$ \\
\hline African American & $0.11(0.31)$ & $0.13(0.34)$ \\
\hline Hispanic & $0.14(0.34)$ & $0.06(0.24)$ \\
\hline Other races & $0.06(0.24)$ & $0.03(0.17)$ \\
\hline Marital status (married $=1$ ) & $0.61(0.49)$ & $0.57(0.49)$ \\
\hline No. of children under 2 & $0.07(0.27)$ & $0.07(0.26)$ \\
\hline No. of children between 2 and 15 & $0.61(0.98)$ & $0.54(0.95)$ \\
\hline Some college & $0.55(0.50)$ & $0.54(0.50)$ \\
\hline High school graduates & $0.22(0.41)$ & $0.25(0.43)$ \\
\hline Less than high school & $0.10(0.30)$ & $0.11(0.32)$ \\
\hline Illness or disability & $0.06(0.24)$ & $0.07(0.26)$ \\
\hline Annual hours worked/1,000 & $1.61(0.010)$ & $1.55(0.017)$ \\
\hline Logged salary & $9.63(0.032)$ & $9.26(0.060)$ \\
\hline Self-employment & $0.082(0.003)$ & $0.077(0.005)$ \\
\hline
\end{tabular}

Note: sample means are adjusted using sample weight. Standard deviations for continuous variables are shown in parentheses. Sample periods is 2007.1-2010.12. 
Next, we include the state-missing sample in our analysis. For observations that have missing state information, we use the average of the unemployment rate and other macroeconomic variables across the 13 states that involve either missing or recoding. The Medicaid generosity variable is generated using the averages of the Medicaid threshold across the 13 states. We exclude the five states that are not included in the CE. While realizing that this method does not provide an ideal solution for the problem at hand, it does suggest the direction of the bias, if any.

In Table 12, we present regression results using the larger sample. We find that the unemployment rate is statistically significant in all categories of care. The coefficients are slightly smaller in the regressions that include the statemissing subsample for overall medical care, physician visits, and prescription drug use, while the coefficient for hospital care is very similar across the two samples. The effect of the unemployment rate on out-of-pocket expenditures is not statistically significant in both samples. When we include only the statemissing observations and exclude the observations being recoded, the results are very similar.

Table 12: Effect of macroeconomic conditions on utilization and expenditures

\begin{tabular}{|c|c|c|c|c|c|}
\hline Dependent variable & $\begin{array}{r}\text { Any medical } \\
\text { care }\end{array}$ & $\begin{array}{r}\text { Physician } \\
\text { visit }\end{array}$ & $\begin{array}{r}\text { Hospital } \\
\text { care }\end{array}$ & $\begin{array}{r}\text { Prescription } \\
\text { drug }\end{array}$ & $\begin{array}{r}\text { Out-of-pocket } \\
\text { expenditure }\end{array}$ \\
\hline Including state-missing subsample & $N=16,954$ & & & & $N=8,693$ \\
\hline Unemployment rate & $\begin{array}{l}0.011^{\star \star \star} \\
(0.005)\end{array}$ & $\begin{array}{l}0.010^{\star \star \star} \\
(0.005)\end{array}$ & $\begin{array}{l}-0.004 \\
(0.003)\end{array}$ & $\begin{array}{c}0.012^{\star *} \\
(0.006)\end{array}$ & $\begin{array}{l}-0.025 \\
(0.023)\end{array}$ \\
\hline Excluding state-missing subsample & $N=12,965$ & & & & $N=7,339$ \\
\hline Unemployment rate & $\begin{array}{l}0.014^{\star \star \star} \\
(0.005)\end{array}$ & $\begin{array}{c}0.010^{\star} \\
(0.005)\end{array}$ & $\begin{array}{l}-0.005^{\star \star} \\
(0.002)\end{array}$ & $\begin{array}{c}0.014^{\star \star} \\
(0.006)\end{array}$ & $\begin{array}{l}-0.027 \\
(0.022)\end{array}$ \\
\hline
\end{tabular}

Note: Each regression additionally controls for all demographic and socio-economic variables, in addition to state, year, and month fixed effects. Standard errors clustered at the year and state level are presented in parentheses. ${ }^{\star *},{ }^{* \star},{ }^{*}$ indicate statistical significance at $1 \%, 5 \%$, and $10 \%$, respectively.

\section{References}

Bertakis, K. D., R. Azari, L. J. Helms, E. J. Callahan, and J. A. Robbins. 2000. "Gender Differences in the Utilization of Health Care Services.” Journal of Family Practice 49(2):147-52.

Brenner, M. H., and A. Mooney. 1983. "Unemployment and Health in the Context of Economic Change." Social Science \& Medicine 17(16):1125-238.

Cameron, A. C., P. K. Trivedi, F. Milne, and J. Piggott. 1988. "A Microeconometric Model of the Demand for Health Care and Health Insurance in Australia." The Review of Economic Studies 55(1):85-106. 
Card, D., C. Dobkin, and N. Maestas. 2008. "Impact of Nearly Universal Insurance Coverage on Health Care Utilization: Evidence from Medicare.” American Economic Review 98(5):2242-58.

Cawley, J., S. A. Moriya, and I. K. Simon. 2014. "The Impact of the Macroeconomy on Health Insurance Coverage: Evidence from the Great Recession." Health Economics forthcoming.

Cawley, J., and I. K. Simon. 2005. "Health Insurance Coverage and the Macroeconomy." Journal of Health Economics 24(2):299-315.

Charles, K. K., and P. DeCicca. 2008. "Local Labor Market Conditions and Health: Is There a Connection and for Whom?" Journal of Health Economics 27(6):1532-50.

Colman, G., and D. Dave. 2013. "Exercise, Physical Activity, and Exertion over the Business Cycle." Social Science and Medicine 93:11-20.

Currie, J., and J. Gruber. 1996. "Health Insurance Eligibility, Utilization of Medical Care, and Child Health." Quarterly Journal of Economics 111(2):431-66.

Davalos, M. E., H. Fang, and M. T. French. 2012. "Easing the Pain of an Economic Downturn: Macroeconomic Conditions and Excessive Alcohol Consumption." Health Economics 21(11):1318-35.

Deb, P., M. K. Munkin, and P. K. Trivedi. 2006. "Bayesian Analysis of the Two-Part Model with Endogeneity: Application to Health Care Expenditure." Journal of Applied Econometrics 21(7):1081-99.

Dehejia, R., and A. Lleras-Muney. 2004. “Boom, Busts, and Babies' Health.” Quarterly Journal of Economics 119(3):1091-130.

Du, J. 2012. "Formal and Informal Care: An Empirical Bayesian Analysis Using the Two-Part Model." Forum for Health Economics \& Policy 15(2):1558-9544.

Duan, N., W. G. Manning, C. Morris, and J. Newhouse. 1983. "A Comparison of Alternative Models for the Demand for Medical Care." Journal of Business and Economic Statistics 1(2):115-26.

Elsby, W. M., B. Hobijn, and A. Sahin. 2010. “The Labor Market in the Great Recession.” NBER Working Paper No. 15979.

Farber, S. H. 2011. "Job Loss in the Great Recession: Historical Perspective from the Displaced Workers Survey, 1984-2010." NBER Working Paper No. 17040.

Freeman, D. G. 1999. “A Note on 'Economic Conditions and Alcohol Problems'." Journal of Health Economics 18(5):661-70.

Freeman, J. D., S. Kadiyala, J. F. Bell, and D. P. Martin. 2008. "The Causal Effect of Health Insurance on Utilization and Outcomes in Adults." Medical Care 46(10):1023-1-32.

Fronstin, P. 2011. "Sources of Health Insurance and Characteristics of the Uninsured: Analysis of the March 2011 Current Population Survey.” EBRI Issue Brief, No. 362, September 2011.

Gilmer, T. P., and G. R. Kronick. 2009. "Hard Times and Health Insurance: How Many Americans Will Be Uninsured by 2010?” Health Affairs 28(4):w573-77.

Gruber, J., and L. Levitt. 2002. "Rising Unemployment and the Uninsured." Kaiser Family Foundation, Menlo Park, CA.

Ham, J. C., and L. Shore-Sheppard. 2005. "The Effect of Medicaid Expansions for Low-Income Children on Medicaid Participation and Private Insurance Coverage: Evidence from the SIPP." Journal of Public Economics 89(1):57-83.

Holahan, J. 2011. "The 2007-09 Recession and Health Insurance Coverage." Health Affairs 30(1):145-52.

Holahan, J., and A. B. Garrett. 2009. "Rising Unemployment, Medicaid and the Uninsured." Urban Institute Policy Brief, January 13. http://www.urban.org/url.cfm?ID=1001241 
Hoynes, H. W., D. L. Miller, and J. Schaller. 2012. "Who Suffers During Recessions?" Journal of Economic Perspective 26(3):27-48.

Latif, E. 2014. "The Impact of Macroeconomic Conditions on Obesity in Canada." Health Economics 23(6):751-59.

Lusardi, A., D. Schneider, and P. Tufano. 2014. "The Economic Crisis and Medical Care Use: Comparative Evidence from Five High-Income Countries." Social Science Quarterly forthcoming.

Manning, W. G., and J. Mullahy. 2001. "Estimating Log Models: To Transform or Not to Transform?” Journal of Health Economics 20(4):461-94.

McInerney, M., and J. M. Mellor. 2012. "Recessions and Seniors' Health, Health Behaviors, and Healthcare Use: Analysis of the Medicare Current Beneficiary Survey." Journal of Health Economics 31(5):744-51.

McWilliams, J. M. 2009. "Health Consequences of Uninsurance Among Adults in the United States: Recent Evidence and Implications.” Milbank Quarterly 87(2):443-94.

Miller, D. L., E. M. Page, H. A. Stevens, and M. Filipski. 2009. "Why Are Recessions Good for Your Health?” American Economic Review 99(2):122-27.

Mullahy, J. 1998. "Much Ado about Two: Reconsidering Retransformation and the Two-Part Model in Health Econometrics." Journal of Health Economics 17(3):247-81.

Ruhm, C. 2000. “Are Recessions Good for Your Health?” The Quarterly Journal of Economics 115 (2):617-50.

Ruhm, C. 2003. “Good Times Make You Sick.” Journal of Health Economics 22(4):637-58.

Ruhm, C. 2005. "Healthy Living in Hard Times." Journal of Health Economics 24(2):341-63.

Ruhm, C. J., and W. E. Black. 2002. "Does Drinking Really Decrease in Bad Rimes?" Journal of Health Economics 21(4):659-78.

Stock, J. H., J. H. Wright, and M. Yogo. 2002. "A Survey of Weak Instruments and Weak Identification in Generalized Method of Moments." Journal of Business and Economic Statistics 20(4):518-29.

Tekin, E., C. McClellan, and K. J. Minyard. 2013. "Health and Health Behaviors during the Worst of Times: Evidence from the Great Recession.” NBER Working Paper No. 19234.

Terza, J. V., A. Basu, and P. J. Rathouz. 2008. "Two-Stage Residual Inclusion Estimation: Addressing Endogeneity in Health Econometric Modeling." Journal of Health Economics 27 (3):531-43.

Vistnes, J. P., and V. Hamilton. 1995. "The Time and Monetary Costs of Outpatient Care for Children.” The American Economic Review, Vol. 85, No. 2, Papers and Proceedings of the Hundredth and Seventh Annual Meeting of the American Economic Association Washington, DC, May 1995:117-21.

Xu, X. 2013. "The Business Cycle and Health Behaviors." Social Science \& Medicine 77:126-36. 